\title{
WestVirginiaUniversity
}

THE RESEARCH REPOSITORY @ WVU

Graduate Theses, Dissertations, and Problem Reports

2012

\section{Inquiry into Place-Based Education in Art}

\author{
Marie L. Drexler \\ West Virginia University
}

Follow this and additional works at: https://researchrepository.wvu.edu/etd

\section{Recommended Citation}

Drexler, Marie L., "Inquiry into Place-Based Education in Art" (2012). Graduate Theses, Dissertations, and Problem Reports. 684.

https://researchrepository.wvu.edu/etd/684

This Thesis is protected by copyright and/or related rights. It has been brought to you by the The Research Repository @ WVU with permission from the rights-holder(s). You are free to use this Thesis in any way that is permitted by the copyright and related rights legislation that applies to your use. For other uses you must obtain permission from the rights-holder(s) directly, unless additional rights are indicated by a Creative Commons license in the record and/ or on the work itself. This Thesis has been accepted for inclusion in WVU Graduate Theses, Dissertations, and Problem Reports collection by an authorized administrator of The Research Repository @ WVU. For more information, please contact researchrepository@mail.wvu.edu. 


\title{
Inquiry into Place-Based Education in Art
}

\author{
Marie L. Drexler \\ Thesis submitted to the \\ College of Creative Arts \\ West Virginia University \\ In partial fulfillment of the requirements \\ for the degree of \\ Master of Arts \\ in \\ Art Education \\ Victoria Fergus, Ph.D., Chair \\ Ronald Aman, Ph.D. \\ Alison Helm, MFA \\ Erika Osborne, MFA \\ School of Art \& Design \\ Morgantown, West Virginia \\ April 2012
}

Keywords: Place-Based Education; Art Education; Community-Based Art, Multidisciplinary Curricula 


\section{ABSTRACT \\ Inquiry into Place-Based Education in Art}

\section{Marie L. Drexler}

A place-based pedagogy is a call for educators to utilize local environs in content curricula to build upon and enrich instruction for students. This study examines the potential for K-12 schools in West Virginia to reasonably adhere to place-based art education methods in visual arts curricula. Data collection consisted of interviews conducted with three West Virginia public school art educators and three community specialists who work in the fields of art, ecology, and art education. Using qualitative analysis, the open-ended responses from both the teachers and the community specialists were analyzed. The conclusion section reviews limitations to placebased education expressed by the educators, and examines how community specialists may create a "bridge" with schools that would facilitate such lessons. 


\section{TABLE OF CONTENTS}

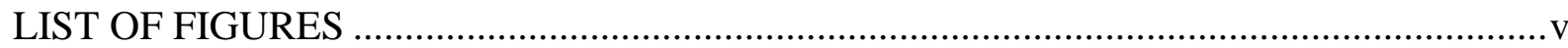

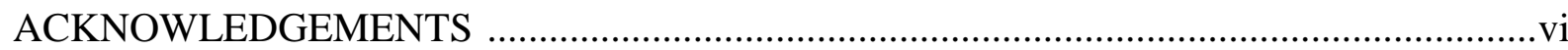

CHAPTER 1: The Problem and the Study .............................................

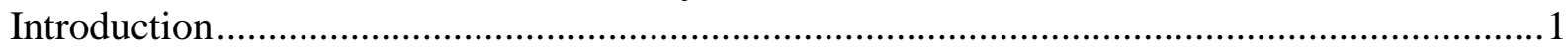

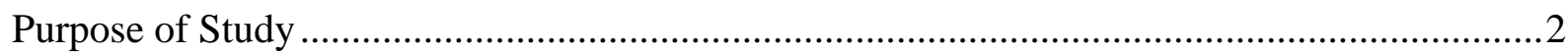

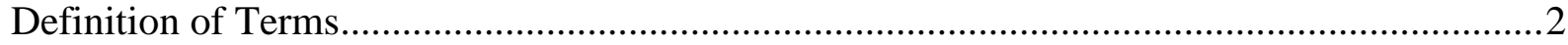

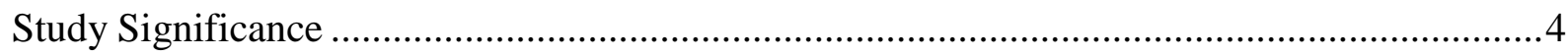

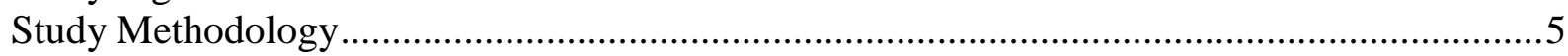

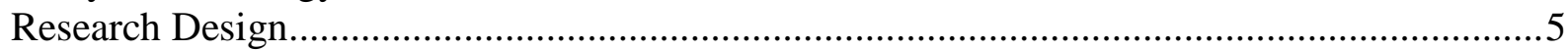

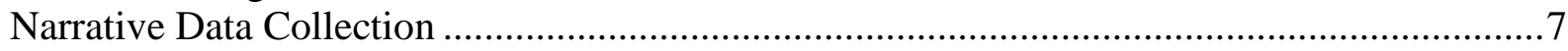

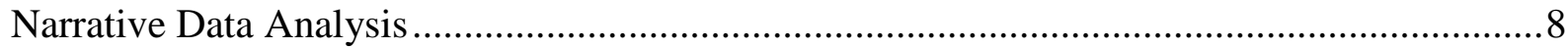

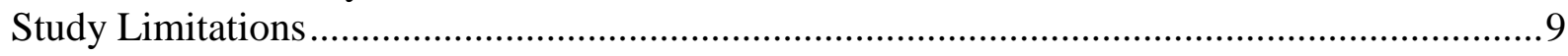

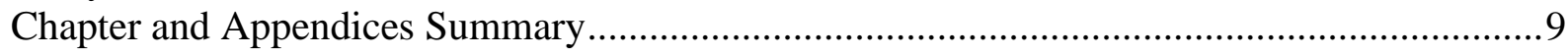

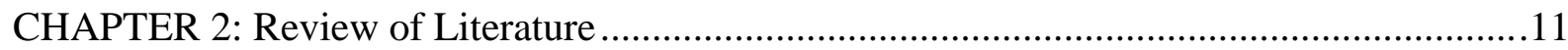

CHAPTER 3: Examples of Place-Based Art and Community Projects ...............................22

CHAPTER 4: Analysis of the Interviews of Art Educators and Community Specialists in West

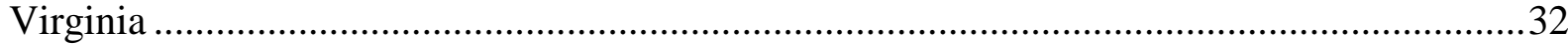

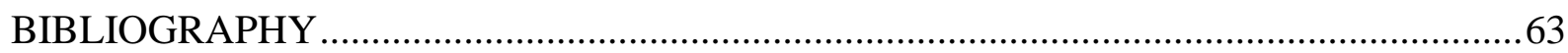

\section{APPENDIX A}

Sample Art Educator Interview Consent Form.........................................................6

\section{APPENDIX B}

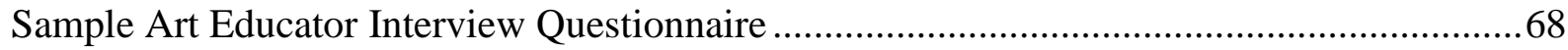

\section{APPENDIX C}

Sample Community Specialist Interview Consent Form ................................................ 71

\section{APPENDIX D}

Sample Community Specialist Interview Questionnaire ...............................................72

\section{APPENDIX E}


Art Educator Interview Responses Transcribed

.74

APPENDIX F

Community Specialist Interview Responses Transcribed.

APPENDIX G

A List of West Virginia Community Programs and Resources ..........................................96

APPENDIX H

Introductory Place-Based Lessons for West Virginia Art Educators ...................................98 


\section{LIST OF FIGURES}

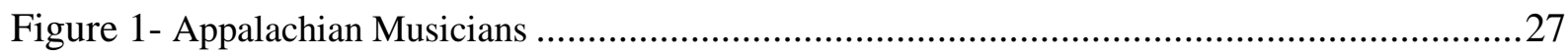

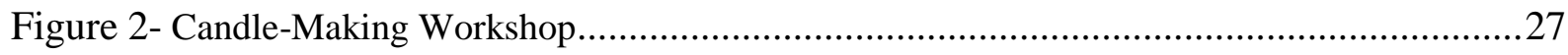

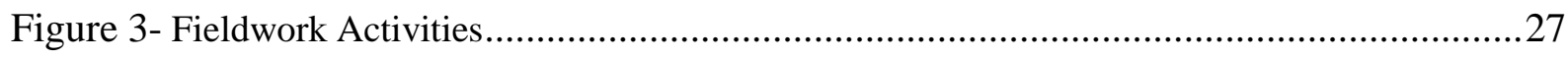

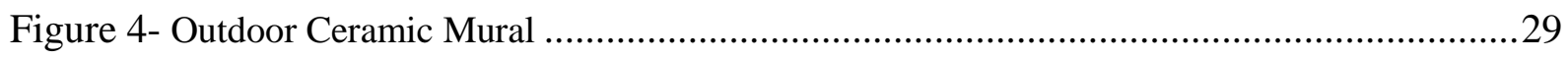

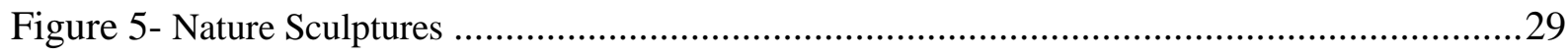

Figure 6- Community Art with an Environmental Message ...............................................59

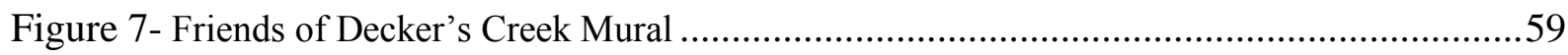

Figure 8- Pocahontas County Installation Mural ............................................................6 68 


\section{ACKNOWLEDGEMENTS}

I would like to thank my committee members for their advice, direction, and support which has enabled me to develop an understanding of the subject. A sincere thank you goes to my advisor, Dr. Victoria Fergus, for the guidance she showed me during my graduate studies and this research project.

I am truly thankful to my mother and father for their unconditional support, both emotionally and financially, throughout my degree. In particular I'd like to acknowledge the love, friendship, and patience shown to me by my mom, which I always appreciate.

This project would not have been possible without the participation of my interviewees, all of the art educators and the community specialists who have graciously helped out.

It is my pleasure to thank those who helped make this thesis possible including Uncle Tim and Aunt Julie. Lastly, I offer my love and gratitude to all those who have supported me in any way during the completion of this project. 


\section{CHAPTER 1}

\section{THE PROBLEM AND THE STUDY}

"Art becomes a vehicle for examining the world in which we live through multiple and critical lenses and for imagining our responsibilities and actions within that world (Bailey \& Desai 2005, p. 39).”

\section{Introduction}

Place-based education is a relatively new teaching philosophy (1990s) which establishes content curricula in local culture, community, and settings. The key to place-centered education, as it is commonly referenced as, is to immerse students in their physical and social surroundings where they actively learn through project-based experiences (Place-Based Education Evaluation Collaborative, 2010). In traditional visual arts education classes, students apply problem-solving skills and critically analyze artworks through action; they also create, observe, discuss and write to communicate ideas. In both place-based education and traditional art education the "core" focus of learning is through student experiences. This study will be examining the potential for K-12 schools to reasonably adhere to place-based art education methods in their visual arts curricula. For the purpose of this paper I have focused on West Virginia as the setting for my research and data collection.

As educators with students' best interests in mind, I believe we need to continually reevaluate teaching strategies in conjunction with contemporary culture and issues. The National Art Education Association's Constitution proclaims in its Preamble that, "it shall be the intent to communicate our belief to the organized teaching profession and the community-at-large, to strengthen the position of the visual arts as a discipline in schools, and to affect positively the role of art education in culture (Baker, 1990, p. 29)." The West Virginia Board of Education policy 2520.12 articulates and guides visual art education to be "delivered with the creative and 
instructional expertise of West Virginia teachers, (which) will become a powerful resource for preparing students to meet the challenges of the $21^{\text {st }}$ century (Paine, 2008)."

\section{Purpose of Study}

Using qualitative and quantitative analysis, this study researched the potential for placebased methods to be integrated into visual art education in K-12 public schools in West Virginia, under the assumption that place-based practices will enhance curricula and improve student learning skills, while adhering to the West Virginia Department of Education's Visual Arts Content Standards and Objectives. Since the goal of place-based art education is to integrate learning with a student's environment, including its history, community, and natural surroundings; this study analyzed current art education practices by sampling a group of West Virginia art teachers. The goal was to determine what level of place-based education is already being incorporated. These teacher inquiries addressed teacher planning, available resources, financial assistance, and lessons. A second group sampled was West Virginia community specialists who work in the fields of art, ecology, and art education. Open-ended responses

from both the teachers and the community specialists were analyzed and included in this study. (See Appendix E and Appendix F)

\section{Definition of Terms}

The following definitions were developed in order to understand the key terms being used in this study.

1. Art is being defined as a reflection of what is observed. "Human creativity is an integral part of the web formed by land, history, culture, and place (Lippard, 1997, p. 18)." 
2. Discovery: A method of instruction that facilitates learning through interactions, explorations, observations and analysis.

3. Place-Based Education: Education curricula which focuses on local history, culture and the environment, in which an emphasis is placed on experiential learning. Also, for this study of place-based education, 'place' focused on West Virginia as the setting for its research.

4. Service Learning: A teaching method that provides opportunities for students to interact with and participate in activities/projects that support their communities including collaborative projects with community organizations.

5. Community: Local area which includes its social, historical, and environmental surroundings.

6. Art Educator: A working K-12 school teacher instructing in the area of visual/ tangible arts, such as drawing, painting, and sculpture.

7. Community Specialist: Working professionals whose community-based programs are intended to help people and educate local students in a specific location; for the betterment of a community.

8. Instructional Scaffolding: Incorporating appropriate learning supports, known information and resources such as place, in content curricula.

9. Constructivist Education: Learning theories in which students gain knowledge and understanding through experiential learning; methods of instruction include discovery learning and cooperative practices.

10. Cooperative Learning: Classroom activities that join academic content with social learning experiences.

11. Cross-Curricular Integration: Applying knowledge and values to lessons through combined content disciplines, such as art, history, and environmental education.

12. Multiple Intelligences: Identifying a student's different talents and cognitive abilities; examples consist of but are not limited to artistic/spatial, mathematical, linguistic, interpersonal, musical, athletic, and naturalistic aptitudes. 


\section{Study Significance:}

This study explores the question, "Is it possible for West Virginia School's K-12 visual arts curricula to follow place-based art education methods?" The hypothesis is that place-based art curriculum is beneficial to public education because it immerses students in environmental studies, local culture, and experiential learning. In place-based education, students are connected to learning projects and opportunities that extend beyond the classroom. The benefits to public school visual art education might include an increase in student motivation and active community/citizenship support efforts, as well as a shift in educators' teaching philosophies that address new and changing agendas, questions, and understandings about art.

This study looks at grounding curricula in "place" which establishes a familiar base from which to learn, supporting the concept of scaffolding in education. Scaffolding is an instructional practice associated with Lev Vygotsky's social learning theories. This instructional practice uses numerous supports to help teach new information during the early stages of learning and then build on this information base (Slavin, 2009; Wood, Bruner, \& Ross, 1976). This study will maintain that local "place" is a structure of support for learning, from which students experience through nature and social interactions, enabling them to build on what they already know from outside the classroom. Student experiences become the base for familiarity and awareness on which art curricula can build.

When grounding art education studies in the community and natural environments of a specific locale, art teaching enhances the process through which students discover, recognize, and celebrate community values (Blandy and Hoffman 1993; McFee 1961). Discovery is a key term, significant to this research's support of place-based art education. The term discovery can imply interaction, exploration, observation and/or analysis. 
By introducing place-based lessons in art education classes, art teachers might promote student achievement through both classroom participation as well as direct experiences. Additionally, through both fieldwork projects within the community and service learning projects, students might gain awareness about the social and environmental issues affecting their local surroundings. This study places significance and value on art educators being able to help students build a relationship with their community or "place."

\section{Study Methodology}

The methodology for this study follows a qualitative research method to organize and then to analyze participants' responses to open-ended questions. Responses from art educators and community program specialists comprise the narrative data.

A qualitative research methodology explores new theories and ideas by interpreting empirical, real world, experiences/perspectives of others. Qualitative research methods study and investigate social phenomena, which are grounded in research theory and world experiences (Ospina, 2004). Qualitative research provides insight about people's attitudes, morals, and behaviors (Maxwell, 2005). In Chapter Four, I evaluated the data collected from art educators and community specialists. The interviewees provided information about their personal experiences, as well as their perspectives on teaching place-based art lessons.

\section{Research Design}

This research was designed to explore the possibility and benefits of integrating placebased art curriculum in West Virginia's K-12 visual art programs. The information was gathered from individual interviews and open-ended surveys (Taylor-Powell \& Renner, 2003). The goal of collecting narrative data was to determine the potential for art educators and community 
program specialists to integrate place-based education in their work. This study focused on discovering information about current teaching practices, school regulations, budget, and work demands associated with educational collaborations.

Informal interviews and open-ended surveys were constructed to collect data from three West Virginia educators and three West Virginia community program specialists. The interviews were performed from January through March 2012, and were based on two separate questionnaires. One questionnaire (18 questions) was designed to gather comments and opinions about place-based education practices from art educators currently working within the K-12 school system in West Virginia. The other question set (8 questions) was geared towards gathering information from the education-based community program specialists in West Virginia, particularly looking at the potential for collaborations with local schools. One questionnaire was meant to determine whether place-based lessons were currently being incorporated in the schools, and the other questionnaire was meant to uncover whether community organizations are willing to partner with school art educators on place-based lessons.

These interviewees selected for the study included visual art educators that I have observed teaching during my Masters in Art, Art Education program. Community program specialists were chosen based on their program's community purpose and education goals. In addition, the selected program specialists work in one or more of the following areas: local arts, environmental education, studio art and art making, and neighborhood service projects.

The data collection process began with gaining permission from the interviewees to participate in the study. The interviewees were mailed consent forms which included brief survey questions. These questions gave initial information about the interviewees' experience 
within the field of education and community programming, such as how long they had been in their professions. The preliminary consent forms are included in Appendix A and Appendix C. Upon receiving interview the consent forms, I contacted interviewees directly by phone or e-mail to schedule interview times. Informal telephone interviews were subsequently conducted, and interviewee responses were recorded by hand, and later transcribed to electronic file format. One or two interviews were conducted weekly, for a total data collection period of approximately ten weeks.

\section{Narrative Data Collection}

Narrative data is comprised of written and oral responses which address questions concerning a study's research topic. This study's narrative data gathering and analysis follow the guidelines set by the University of Wisconsin's Program Development and Evaluations handbook, written by educators Ellen Taylor-Powell and Marcus Renner.

Data was collected from oral responses to informal interview questions. Interviews included open-ended questions, and responses were transcribed by this researcher. Interview sessions began with a description of an example of a West Virginia place-based art lesson which had been a collaborative project between a school and a community program. This example used to introduce the topic of place-based education.

The intent was to discover current educators' teaching experiences and personal reflections in regards to art education and the local community. The data collected has enabled the researcher to analyze the potential for integrating place-based lessons into visual art content studies. Additionally, data was analyzed to determine whether community programs were willing and/or prepared to assist with public education, specifically in reference to visual arts education. Visual art curriculum that is place-based teaches about the integral relationship 
between art, art making, and place (Freeman, 2000; Lai \& Ball, 2002). The purpose of this study was to provide a clearer understanding of how to integrate place-based lessons into art education.

\section{Narrative Data Analysis}

After completion of the narrative data collection and transcription, I created a list of categories that seemed to capture the main themes addressed in the interview responses. Each category was assigned an abbreviation code. The narrative data categories and their abbreviation codes are as follows:

\section{NARRATIVE DATA CATEGORIES}

Benefits to Place-Based Education $(B E)$

System Limitations (SL)

Environmental Art and Education (EA)

Field Studies $(F F)$

School Policy $(S P)$

West Virginia Content Standards and Objectives (CSO)

Example Projects (EP)

Education Collaborations (EC)

Community Outreach $(\mathrm{CO})$

Program Classes (Community) (PC)

Next, each of the fifty-four responses from the educators was analyzed, and the twentyfour responses from the community specialists. I assigned a code from the categories listed above to each response. This coding enabled me to evaluate the similarities and differences in interviewee responses, and led me to create charts that would visually illustrate the results.

A qualitative study breaks down data into categories which can be applied to a research study's formative theories (Golafshani, 2003), and the effectiveness of a qualitative research study relies heavily on the validity and reliability of its process. Nahid Golafshani's (2003) Understanding Reliability and Validity in Qualitative Research defines such terms as the quality of trustworthiness with which research is carried out and collected. During my data collection, I ensured that every interview was performed consistently. 


\section{Study Limitations}

This study focused on the potential for place-based studies to be integrated into visual art education in K-12 West Virginia public schools. Although it would be useful to expand this study to interviewing all of West Virginia's K-12 art educators, my data collection was limited. The sample size for this study included three highly experienced visual art teachers and three community program specialists/educators who agreed to be interviewed, and whose responses were used.

I understand that this study's data collection and analysis depends on the art educator's subjective responses to their own experiences, therefore, I was limited to drawing conclusions about the potential benefits of integrating place-based art education based on subjective responses. Based on narrative data collection and the literature review alone, I acknowledge that my conclusions about the integration of place-based art education in West Virginia curriculum have limitations. The data collected for this study is not definitive.

\section{Chapter and Appendices Summary}

Chapter One provides the study's purpose, definition of terms, study significance, methodology, and limitations.

In Chapter Two, a review of literature includes the benefits of both place-based curriculum and place-based art curriculum.

In Chapter Three, examples of place-based lessons are provided that have been successfully implemented by teachers, community programs, and schools, and discuss the benefits of these lessons to students.

In Chapter Four, I present my analysis of the narrative data collected in interviews. In addition, this chapter contains recommendations for further studies and research. 
The Appendices have included the following: Sample Art Educator Interview Consent Form (Appendix A), Sample Art Educator Interview Questionnaire (Appendix B), Sample Community Specialist Consent Form (Appendix C), and Sample Community Specialist Interview Questionnaire (Appendix D). Transcribed and coded interview responses for art educators are in Appendix E, and community specialist's responses are in Appendix F. Additionally, West Virginia community programs and resources were listed in Appendix G, as an assist to educators interested in learning more about place-based education and potential collaboration opportunities. Finally, Appendix H contains three place-based art lesson plans, at three target grade levels, which were created as introductory place-based lessons for West Virginia art educators. 


\section{CHAPTER 2:}

\section{REVIEW OF LITERATURE}

\section{Overview of Place-Based Education}

Place-based education is a teaching philosophy intended to enhance content curricula by immersing students in their local community environments. Core curriculum studies such as art, science, language arts, social studies and reading can promote studies that are place-based, often including projects that are hands-on and/or address real local issues. Place-based education seeks to bridge the gap that lies between school curricula and students' lived experiences; to nurture their interests in the actual phenomena of their surroundings (Smith, 2002). This study proposed that content curricula in art education in West Virginia be enhanced so that students' experiences as well as their knowledge of 'place' become a vehicle for learning.

Place-based practices follow the content standards and objectives set by West Virginia's Department of Education, while also supporting a more multifaceted curriculum which investigates 'place' and offers opportunities for discovery learning and study explorations. Such a curriculum in art education would be grounded in the first-hand experiences students have with the places in which they live because art making is a practice most closely tied to the place and community from which it was developed. "Human creativity is an integral part of the web formed by land, history culture, and place (Lippard, 1997, p.18).”

Place-based art education calls for an instructional method that is interactive and integrates a constructivist approach (Inwood, 2008). Research on place-based education indicates several, reoccurring, advantages for teaching students place-centered content studies in schools. The principle advantages for students are: 
- Learning the Community Centered Approach of Place-Based Education,

- Learning the Fieldwork Approach of Place-Based Education,

- Learning Collaborations in Place-Based Education,

- Learning Cross-Curricular or Multi-Disciplinary Approaches in Place-Based Education.

In researching educational theories that specifically mention place-based learning, these advantages were frequently referenced.

\section{The Community Centered Approach of Place-Based Education}

Place-based projects commonly include interviewing community members, having public speakers come to the classroom, and students visiting community buildings, businesses, and programs. "Community recognizes art and art making as integral to the discourse that shapes and defines community interactions and activities (Blandy \& Hoffman, 1993, p 25)." Art can be unifying to a community because it invites all members to participate within their local environment. Community art can be unstructured and free flowing. "Learners are influenced by, and at the same time push back, take from, change, control and create the environment in which learning is situated (Alexander, Schallert, \& Reynolds, 2009, p. 180).”

\section{The Fieldwork Approach of Place-Based Education}

Community projects regularly include fieldwork, the second principle or advantage of placebased art education, in which students visit and experience first-hand their natural and social communities. John Dewey (1934) and Gregory Smith (2002) both argue that students are drawn to real world occurrences which cannot be replicated within a school environment. These educators write that learning should extend beyond the classroom walls, allowing students to get involved and interpret their social and natural environments. It is particularly relevant to develop 
students' sensory and aesthetic awareness by using natural materials to create art, sketching on site, and analyzing the function and look of a place and its resources. Particularly with students today who are overwhelmed by visuals from media and technology resources, fieldwork refocuses their attention to observe and investigate the specifics of place. One educator stresses that, "as a culture we are beginning to reconnect the functions of our human-made environment to the functions of the natural-made environment (Hansen, 2009, p. 47)."

\section{Collaborations in Place-Based Education}

Collaborative work, the third principle advantage of place-based education, draws on multiple strategies for teaching instructions, such as discussion and writing based activities. Scaffolding in education follows Lev Vygotsky's theories on social and cognitive development and identifies discussion-based learning as an instruction support. Social learning theories recognize that through talking, students develop problem solving skills allowing them to think out loud with the input and support of their classmates. Vygotsky argued that a student's early thinking comes from social interactions, and that thought development is not an individual activity (Derry, 2008). In place-based education, the teacher is a guide for learning by pointing out details of the student's environment that should be observed and discussed. Place-based education can guide young students, while developing their knowledge base, about how to observe details in their environments. Theorist Matt Sanger (1997) believes that stories of place are part of a greater approach to learning. Through interviews and discussion, students can learn more about their environments. For example, interviewing local farmers about their land can help students understand and think about the story behind that land, such as its function and purpose. If students brainstorm on a local topic through journaling and also group discussions, they may gain a better understanding and awareness of their environments. Natural 
environments are rich in opportunities for teaching about core subjects, such as science and social studies content.

\section{Cross-curricular or Multi-discipline Approaches in Place-Based Education}

A cross-curricular teaching approach, another reoccurring principle advantage in the literature of place-based education, means teaching content curricula that goes beyond single subject studies and integrates several subjects in one lesson. Teaching integrated curricula, such as art and environmental education or earth science, may help students to make significant connections between the subjects. Several researchers, including Smith (2002), Blandy \& Hoffman (1993), and Graham (2007 b) all promote art education that focuses on the issue of environmentalism. These educators are in support of place-based art education that illustrates elements of the visual arts in association with environmental education. Inwood (2008) believes that teaching ecological and environmental education in conjunction with the visual arts establishes a more creative, affective, and sensory approach to learning. "An art education [of place] has proven to be the fertile soil in which to grow creative approaches to problem-solving, critical thinking, and self-reflective learning (p. 31).”

\section{Benefits of Place-Based Curriculum}

Place-based education immerses students in learning beyond the classroom by means of examining local culture, history, and natural environments as foundations for learning content curricula. In the brochure The Benefits of Place-Based Education: A Report from the PlaceBased Education Evaluation Collaborative (2010) qualitative data is collected from students, educators, and community adults participating in place-based programs, reflecting the effectiveness for this method of education. The Place-Based Education Evaluation 
Collaborative (2010) conducted ten studies across the United States which maintain that placebased learning can positively affect academic achievement. "Educators at sites using placebased education models consistently report that students have become increasingly engaged and enthusiastic about learning (p. 2).”

Another benefit of place-based education is that through fieldwork and collaborative studies, students become aware of local issues. Connections built between the school and the community encourages students to become active citizens (Place-Based Education Evaluation Collaborative, 2010). Educators Blandy and Hoffman (1993) assert that place-based art education can assist students "understanding of the interdependence and interconnectedness of all things (p. 28)." Research on place-based education has a reoccurring value placed on educators and students "responsibility to conserve and restore our shared environments for future generations (Gruenewald, 2003, p. 6).”

The brochure The Benefits of Place-Based Education (2010) also draws attention to similar studies in which students who are exposed to quality place-based lessons outperform schools in various subject areas, particularly in math and science (p. 2). Students often gain a better understanding of concepts when they participate in activities that experience place in correlation with education (Place-Based Education Evaluation Collaborative, 2010). Educators Smith (2002), Ruppert (2006), and Place-Based Education Evaluation Collaborative (2010) help support the idea that art and place-based education positively affect student academics and school achievement.

Linking curricula with local contemporary agendas can be beneficial to teachers, as well as students, by challenging educators to continue their own learning. This too could help foster 
professional connections in the community for teachers to develop projects and form collaborations with community outreach work that connects with school education (Place-Based Education Evaluation Collaborative, 2010).

In place-based education there is a focus on incorporating team collaborations and group discussions for students to discover new information together with peers. As Bruner (1966) advocates, "we teach a subject not to produce little living libraries on that subject, but rather to get a student to think (p. 72).” A collaborative approach to teaching, working with peers to create, discuss and reflect on their local environments can promote sensory awareness that leads to critical thinking and discovery learning.

In educational psychology, constructivism means the cognitive ability of a child to create systems of meaning and understanding through experiences and interactions (Slavin, 2009; Berk, 2006; Cook \& Cook, 2007; Wadsworth, 2004). According to this theory, students are able to build on their current knowledge base by assimilating new information from their personal experiences and surrounding environments. Thought development may result from studies and learning that goes beyond a classroom.

In addition to place-related lessons, place-based education is typically associated with community-centered education. Community-centered education includes practices such as students learning about a specific subject/topic by interviewing community workers or by visiting and participating in community projects (McFee \& Degee, 1997). In much of the published research surrounding place-based education and place-based art education, educators advocate teaching content that directs attention to local and environmental issues (Hicks \& King, 
2007). Teaching content in this way challenges students to analyze and learn from the direct experiences they have with school projects that involve local materials and place.

\section{Benefits of Place-Based Art Curriculum}

The benefits of place-based art education have far reaching effects which can extend throughout the school and community. Visual arts content goals and objectives for K-12 education in all of West Virginia focus on developing meaningful academic curriculum that aids in teaching students critical thinking skills. The goals and objectives in a place-based art curriculum would additionally target students' attentiveness to sensory experiences to achieve a better understanding of how history, culture, and art influence each other. Sandra Ruppert (2011) in Critical Evidence: How the Arts Benefit Student Achievement points to art education as a contributor to comprehensive and academic success (p.3). Educator Gregory A. Smith in Place-Based Education: Learning to Be Where We Are (2002) cites a place-based Environmental Middle school in Portland, Oregon as example of students that "consistently perform at high levels in comparison to their peers in other schools (p. 589)."

Collaborative approaches to teaching place-based education use multiple teaching strategies, such as working with peers to produce artwork, and to discuss/reflect on projects (Sanger, 1997). When students work collectively through art production activities, discussions, and critiques, these activities help students learn problem solving and critical thinking skills. In this approach, students work as a team to explore real world, local problems and agendas, to assimilate new ideas, perspectives, and knowledge. Collaborative and team learning can help produce active contributors to the community and to help students see value in supporting their local environments (Sanger, 1997). "This principle is used to support the classroom use of 
projects, simulations, explorations in the community, writing for a real audience, and [developing] other authentic tasks (Slavin, 2009, p. 232).” By challenging students to explore real problems, as a team, they can draw critical connections between information learned in the classroom and real world agendas.

Art education practices emphasize how to utilize classroom resources, such as readings, videos, and technology aids to help present visual art content. Content resources, such as published textbooks and technology materials are readily marketed and available to teachers across the United States. Instructional guidance and illustrative examples are readily presented by these teaching resources; however these resources provide generic models of instruction that focus on developing national standards and vocational skills (Gruenewald, 2003, p. 3). Placebased art education calls for an instructional method that is more directly interactive and supportive to a constructivist approach (Inwood, 2008).

An art education that is place-based promotes and values education which continues to develop and move forward (Place-Based Education Evaluation Collaborative, 2010). Thus place-based art education may have the potential to transform a school's culture by establishing a shared mission that extends learning beyond the school/classroom and into the real world. Fieldwork in education most closely relates to the interactive experiences that students physically have with learning. A fieldwork project might be collecting, touching, and sketching the different natural materials and textures from a local community park. John Dewey (1934) recognized lived experiences as having intellectual and aesthetic qualities. The intellectual quality of these experiences challenges students to recognize connections between classroom content and the real world. The aesthetic quality of these experiences can increase the student's social and sensory awareness, which can help promote learning. 
Place-based education highlights cross-curricular approaches to teach, integrating subjects together into one curricular lesson to foster students' critical thinking abilities, building connections between subjects and students' environments. The visual arts have the ability to create a more imaginative and open teaching agenda, to expand learning beyond content specific studies. In a cross-curricular teaching approach using place-based art education, students can learn information for different content studies through imaginative and engaged discovery learning practices. Educators Fettes and Judson (2011) identify that imagination is a key component to learning. Imagination in this case is defined as a "mental capacity, shaped through culture and individual history, which imparts a kind of creative energy to our understanding of the world (p. 125)." These educators recognize the learner's imaginative development as central to the understanding of place.

Cross-curricular teaching in an art curriculum means incorporating visual arts, art history, production, and design, with subjects such as science, English, environmental education, and social studies. Educator Hilary J. Inwood (2008) makes a case for cross-curricular education and visual art education stating that this integration creates a balance between the fundamentals of content discipline and creative, sensory teaching approaches. "Art education has proven to be fertile soil in which to grow creative approaches to problem-solving, critical thinking, and selfreflexive learning (p. 31).”

Lessons that incorporate art production activities and visual, sensory, experiences with multi-disciplinary studies can help students to retain information learned. Developing lessons centered on place creates a paired-association for students, linking the visuals and their experiences, through fieldwork, to content learned. In this way paired associations can be established between place-based lesson information and the sensory experiences a student has 
had with a specific place. One method for enhancing memory is through the use of imagery to create stories that help to weave together information (Egan, 1989). In place-based education the 'stories' and 'images' refer to the local history and culture of a specific community, such as the history and developments of West Virginia culture.

A significant part of place-based education is the emerging belief that art and art education can help contribute to learning about our social and natural environments. Educators Laurie E. Hicks and Roger J. H. King (2007) consider "visual culture [as] inherently civic and community-based (p. 334).” Art and art making have a reciprocating relationship with the community in which it is associated (Blandy and Hoffman, 1993; McFee, 1961). Local art/art making and community bonds can be a point of exploration for visual art education, from which students can engage in learning through experiences. In place-based education, teachers are challenged to build connections between subject content using supportive lesson materials, examples, and strategies. Community and local environments that are part of a place-based teaching approach can be resourced as teaching materials or as visual/art examples for content lessons. For visual art education, teachers examine content goals and then tie these goals to projects where students explore art production activities that contribute to and are inspired by local places. Students can "discover, recognize and celebrate" the community arts and create works inspired by place (Blandy \& Hoffman, 1993, p. 25). Interactions with these environs might also contribute to increased visual awareness of qualities of design that relate to art and the environment.

'In schools, especially after the early elementary grades, teachers direct children's attention away from their own circumstances and ways of knowing toward knowledge from other places that has been developed by strangers they most likely will never meet (Smith, 2002, 
p. 586). Although it is valuable to expose students to unfamiliar concepts and images, this type of instruction could instead begin with concepts from students' known environment and move to the unknown, through discovery learning practices. For instance, a traditional lesson on the architecture of buildings might be based on Greek and Roman architecture. A place-based lesson would have students look for Greek and Roman themes in local architecture. Centering school projects on place-based education practices creates experiences that raise student awareness in relation to local agendas. It is crucial to promote learning in which future generations begin to care for the environments where we live (Hicks \& King, 2007). 


\section{CHAPTER 3}

\section{EXAMPLES OF PLACE-BASED ART AND COMMUNITY PROJECTS}

Place-based art education practices promote opportunities for students to become involved in community-centered or service learning projects. "[Place-based art education's] practices and purposes can be connected to experiential learning, problem-based learning, constructivism, outdoor education, indigenous education, environmental and ecological education, [and to] community-based education (Gruenewald, 2003, p. 3).”

Over the past century formal community and community art-based organizations across the United States have increased, and now provide more opportunities for students and citizens to learn about local agendas and art (Ulbricht, 2005). Following is a sampling of place-based projects in North Carolina, New York, and Maine.

\section{Story Quilts}

One example of a place-based art lesson, with a community-centered approach, is the service learning project by Pamela Harris Lawton, professor at the University of North Carolina; who assembled volunteers and students to work with the Urban Ministry Center in Charlotte, North Carolina to create art quilts. The Urban Ministry Center is a faith based organization devoted to providing for the needs of the homeless in downtown Charlotte, North Carolina. Students and volunteers asked Urban Ministry's community patrons to orally and visually tell their stories through the quilt making process. Lawton says of her project, "Within the scope of [our] service learning project, students learned from the people they met, interacted with and got to know (Lawton, 2010, p. 8)." This particular project explored the issue of homelessness by making quilt patches, to visually tell stories of community members in downtown Charlotte, North Carolina. This project illustrates what Lawton describes in discussing student work, "as a 
curricular tool, service learning makes use of formal, academic, learning within real-world settings, providing students with an opportunity to apply what they have learned to the benefit of themselves, their collaborators and the wider society (Lawton, 2010,p. 8)."

\section{Identifying and Creating Special Places}

An example of a cooperative lesson plan in which students discuss and journal to inspire art making is a project done by educator Mark A. Graham entitled Exploring Special Places (2007). Graham asked his Long Island, New York students to think of a place that was "special" to them. To begin this activity, students discussed what was meant by "special place" and how artists throughout history depicted their environments through art. Students identified their interpretations of place. Following these discussions, the students went into the community to explore different local places. Students worked cooperatively taking pictures and developing preliminary sketches to be used later to incorporate, and inspire, studio work. Back in the studio, art students were free to produce artworks using whatever art media they chose. One student drew images of a street bench on her block and the stairs leading to her sidewalk. Another student created a photographic collage of various street scenes from the main parts of Long Island. Students then prepared written commentaries describing their "special place," as well as how their artworks visually depicted Special Places. The students worked together to mount and hang their artworks in a collective exhibition that included their visual and written commentary. The collective exhibit was opened to the community and was intended to reinforce to students the idea that "art can engage [students] in a reflective and social process with the larger community (Graham, p. 18).”

\section{Exploring Natural Habitats in Maine}


One example of discovery learning, which includes fieldwork explorations, in an art curriculum of 'place' is Erica Hansen's ecologically-based elementary art lesson. This lesson taught students about their natural environments in Lobsterhaven, Maine. Field experience became a resource for her ecological-based lessons where students took trips to specific locations to seek ideas that would inspire art activities linked to these sites. This lesson involved guest speakers, environmental specialists, and talks to students about natural, local habitats. In Hansen's art lessons, students made sculptures, maps, and shadow puppets of local birds and their natural habitats. Also, students designed and made bird houses for native bird species. Students completed sketches on site, to be used later for making shadow puppet designs. "Through their thoughtful designs, the students demonstrated an understanding of the true ecological nature of environment, in which all things are related and affected by each other (Hansen, 2009, p. 51).”

\section{Examples of West Virginia Place-Based Art Education Projects}

Since this study explored integrating place-based education into local West Virginia public schools, the following three examples of place-based education and community projects are included because they were done in collaboration with local schools in West Virginia. These art education projects were completed with the participation of community education programs and several local West Virginia schools. This information was discovered during the interview process of my study, and was provided by community program specialists.

\section{Randolph County Outdoor Education Program}

The Randolph County Outdoor Education Program was done in collaboration with the Mountain Institute's chief Appalachian Program. The Mountain Institute’s Appalachian Program is located in Monongahela National Forest which is part of Northeastern West Virginia. 
The Mountain Institute's Appalachian program began in 1972 and focuses its efforts on "developing an understanding and appreciation for the complex interaction between community, culture, and conservation in Appalachia (The Mountain Institute, 2010).” The Appalachian program has a youth education program which reaches out to local students/public schools and teaches about the values and importance of its region's cultural and the natural environments.

This project includes a three day residency program designed to include all fifth grade classes from the public schools in Randolph County, West Virginia. The residency is an outdoor education-based program that teaches about West Virginia's natural environments and its Appalachian heritage. The program's developers believe strongly in the idea that "learning experiences grow out of a sense of place (The Mountain Institute, 2010).”

The Randolph County Outdoor Education Program takes place at a 4-H Youth Development camp in Beverly, West Virginia, for three weeks in the fall (October) and spring (April). This double session ensures that there are times available for all local fifth grades to participate. Fifth graders involved in this program explore local forests and wetlands; they discuss local issues; and they keep journals about their experiences (The Mountain Institute, 2010). As a means to immerse students in learning more about the culture of this region, the residency offers a heritage program which includes art-based activities that contain lessons about regional arts and crafts and music. Art activities teach about the history of art, as well as the process and technique for creating traditional West Virginia arts and crafts.

The art lessons that are part of this residency program reflect place-based education practices. They include: talking to local artists, watching live art demonstrations on techniques, and developing/creating students' own artworks. As one part of the heritage program, local 
artists who make traditional instruments are invited to the camp where they play Appalachian music for the students. In this way, students learn more about regional music through first-hand experiences. These community musicians are invited to talk/play for students, continuing to honor the art of traditional Appalachian music.

Other arts activities that are part of the Randolph County Outdoor Education project include a workshop on candle-making, where local candle-makers demonstrate to students the process and technique for creating candles. After watching the candle-making demonstrations, students are invited to participate in the craft making process to form their own candles. Each fifth grader gets to make and take home their candle.

On the last day of the Randolph County Outdoor residency program students are given a large piece of paper and asked to create a two-dimensional design for an "imaginary plot of land." Students have creative control to incorporate any visual imagery they choose and can include businesses, homes, trees, etc. However, these imaginary plots each include a stream running through their land, from the top of the paper down to the bottom. Students use creative problem-solving and design to draw/paint/ color their imaginary land maps. Following this creative activity, students discuss community planning and what factors might affect the look and function of a place. Further, these discussions tie into an environmental lesson on water quality and visually teach students about cause and effect, with reference to what is built on the land upstream and how that relates to what is situated downstream. This activity reflects multidisciplinary connections in which students can analyze connections between environmental education and community design/planning. Each of these art-based activities reflect place-based education that has successfully been integrated into West Virginia public education/curricula. 

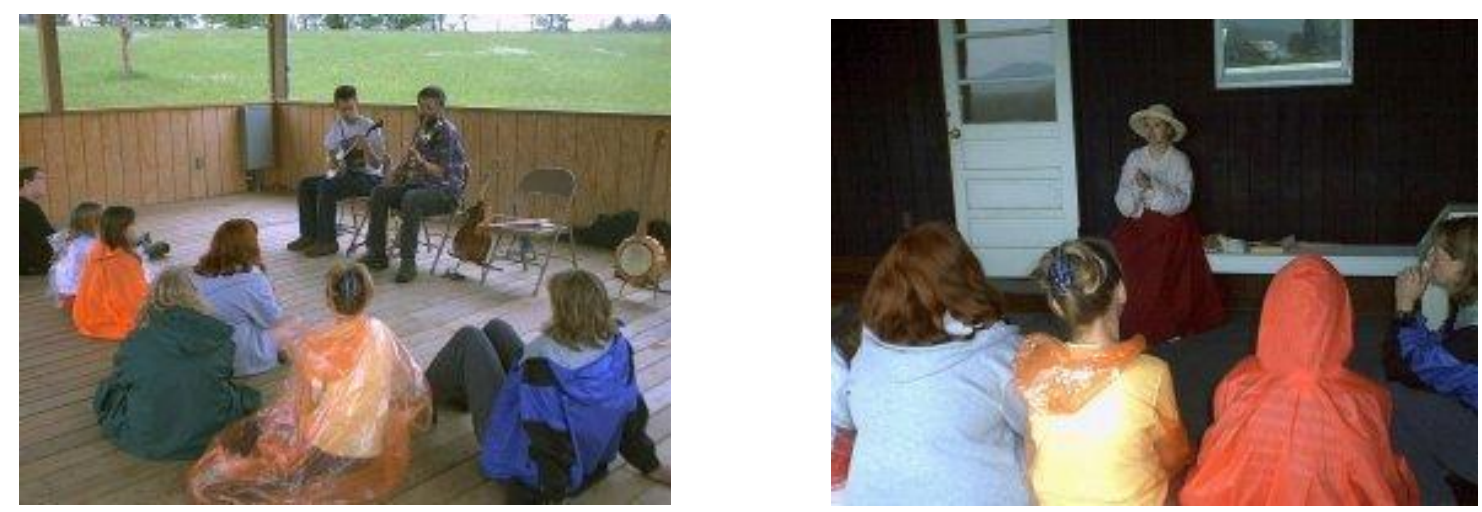

Figure 1- Appalachian Musicians (Above Left) -Local musicians talk to $5^{\text {th }}$ graders about Appalachian music and instruments, and then play for the students participating in Randolph County's Outdoor Education Program. This is one example of a cultural activity that is presented during the three day learning event.

Figure 2- Candle-Making Workshop (Above Right)-A cultural and craft-making workshop is presented at the Randolph County Outdoor Education Program. Above, students watch a local artist demonstrating how to make candles, and then participate in this hands-on activity.

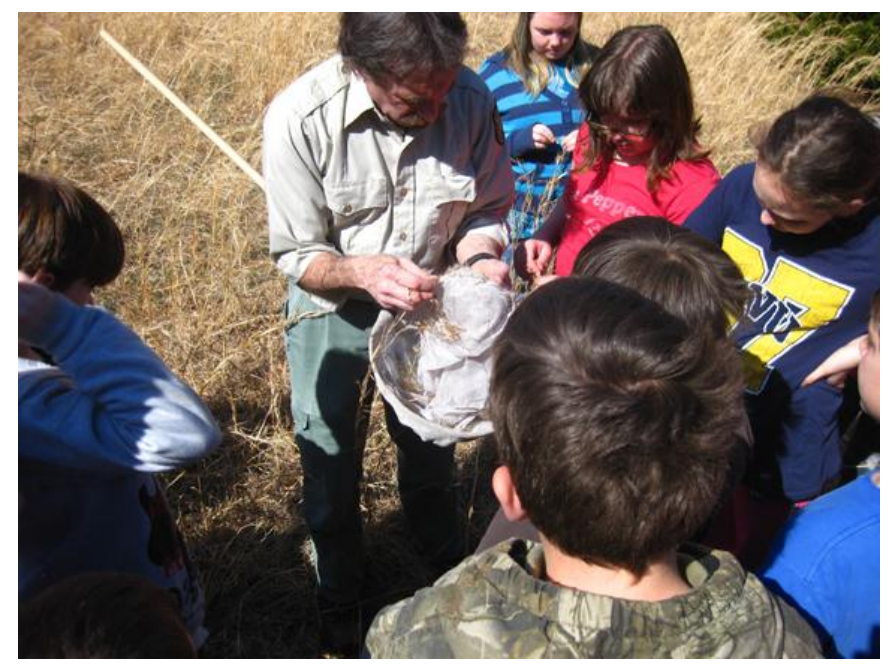

Figure 3-Fieldwork Activities (Above) -An instructor from the Randolph County's Outdoor Education Program, part of the Mountain Institute Program in Spruce Knob, guides students on education-based fieldwork activities.

\section{Stifel Schrader Environmental Education Center}

This place-based lesson is an example of a cooperative learning project that directs

student's attention to their environment. It is also an ecology lesson done in partnership with one

West Virginia public school and the Schrader Environmental Education Program. This ecology 
lesson was taught to one fourth grade public school class in Ohio County, West Virginia. Students learned a horticulture lesson about the state's tree: the sugar maple. This lesson included cooperative activities in which students gathered recycled materials, such as cardboard and paper scraps, to make paper-mache tree form sculptures. As part of this lesson, Schrader educators took students outdoors to observe and discuss with peers the characteristics of real sugar maples. Later in this lesson, students worked as a team to collect more recycled paper which was pulped; they made a water and paper mixture, and made new recycled paper. The recycled paper was then used to make the leaves for their sugar maple tree form sculptures. Students stenciled and crafted leaves using drawing media and took care to closely match their leaf designs with actual sugar maple leaves. Throughout the project, students discussed characteristics, aesthetic qualities and the function of sugar maple trees. Additionally, students sampled locally produced maple syrup.

To exhibit the tree sculptures, a two-dimension collage backdrop was designed by students. This backdrop was comprised of two-dimensional artworks hand drawn and pieced together by the students, the end product was similar to a paper quilt. The collage was inspired by one of Van Gogh's outdoor paintings; students looked at and discussed Van Gogh's work prior to decorating their portion of the collage. This entire lesson reflects a cross-curricular teaching approach that allows for subject integration. Fourth grade students took part in this project-based lesson which combined science, horticulture studies, with the visual arts, using creative problem-solving to design and create artworks based on their natural surroundings. 

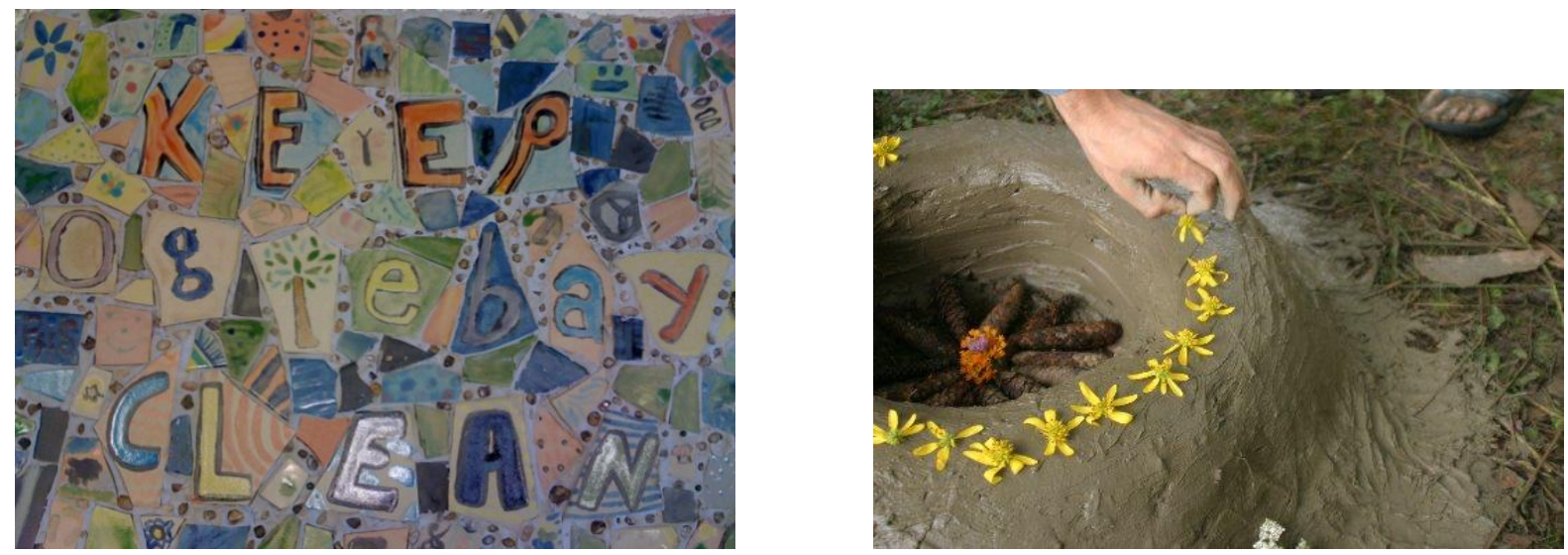

Figure 4- Outdoor Ceramic Mural (Above Left) - Ceramics painted and designed by one Special Education Program at a local school in Ohio County, WV. This picture is an example of a collaborative arts project that was done with the Stifel Schrader Environmental Education program and local students. This tile mural expresses an environmental message in regard to pollution.

Firgure 5- Nature Sculptures (Above Right) -The Stifel Schrader Environmental Education has collaborated with local student to participate in art making activities creating outdoor installations using natural materials.

\section{Stifel Fine Arts Center and St. Francis Xavier School}

A third example of place-based art education project in West Virginia is part of an extended history lesson jointly carried out by The Stifel Fine Arts Center and St. Francis Xavier elementary school. This place-based lesson is currently being taught in the spring of 2012, and is themed around West Virginia history and culture. St. Francis Xavier School of Moundsville, West Virginia received grant funding for a [semester long] project entitled Backyard History. This "Backyard History" project focuses on the Northern Panhandle of West Virginia and the region's rich culture, history, and nature. This extended curricular lesson integrates the arts with disciplines such as science, social studies, and reading/language arts.

One portion of this extended, multi-disciplinary, project includes grant funding for St. Francis Xavier School to work with the Stifel Fine Arts Center on a visual arts project. The Stifel Fine Arts Center is an educational facility which is part of the Ogelbay Insistute in Wheeling, West Virginia. During this project, Stifel's educators visit St. Francis Xavier to teach 
a two-dimensional visual arts lesson. Students are shown how to create original artworks, using illustrations based on Mr. Tom Breiding's, a local musician from Wheeling, West Virginia songs. Students determine the potential content for their artwork based on elements of sound and the lyrics and message conveyed by the songs from the album Unbroken Circle: Songs of the West Virginia Coalfields. The students listen to Breiding's music in order to develop visual symbols and to communicate meaning through their artworks. Also, to more deeply connect students in this arts project Mr. Tom Brieding made a guest appearance to the school in November where he preformed for the school and talked with students about the history of the West Virginia coal industry.

\section{Benefits of Example Projects}

The working examples of place-based education that I provided each include some component of project-based, cooperative, and discovery learning that helps "promote the values and strengths of formal education to bridge the gap between art understandings of different communities (Ulbricht, 2005, p. 8).” Place-based art education possesses opportunities for educators and students to explore the concept of community as 'place' through interactive projects and educational experiences (Blandy \& Hoffman, 1993). All these West Virginia-based projects have been effectively achieved through the cooperation of community center educators and local schools.

In the place-based projects above, there were many benefits to the students. One benefit was students becoming aware of local issues and agendas as they participated in improvement and renewal projects. Students met and talked with community representatives who introduced them to career opportunities such as non-profit arts, environmental protection, and landscape 
design. Many of the projects incorporated community artworks, made collaboratively with the school and the community. Additionally, lessons on recycling were integrated with art production. Thus, the place-based projects provided the students some knowledge and some practical tools they could use to positively contribute to their community. It is a great benefit of place-based education to "train the next generation of [community] decision makers (Janelsins, 2012)."

\section{West Virginia Community Programs and Resources}

A list of West Virginia community programs and resources, located in Appendix $\mathrm{G}$, contains helpful information for West Virginia educators who are interested in integrating place-based art practices into their classroom curricula. This list includes community organizations that offer art classes, education programs, workshops, and environmental education programs. In many cases, these organizations have worked in collaboration with public schools, and would provide grant funding for place-based project collaborations with local public schools. 


\section{CHAPTER 4}

\section{ANALYSIS OF THE INTERVIEWS OF ART EDUCATORS AND COMMUNITY SPECIALISTS IN WEST VIRGINIA}

\section{Description of Data Analysis}

The primary objective of this study was to determine the possibility or the degree of receptivity for the integration of place-based education into visual art curricula in $\mathrm{K}-12$ public schools. In order to evaluate the potential for integrating place-based practices into the visual arts curricula, a survey of some of the people involved on their views of placed-based education was taken. Each of the art educators was interviewed with the same set of questions, and the same set of questions were used for each community specialist. Their responses were then recorded and analyzed for the purpose of determining whether or not these educators and specialists viewed placed-based education as “workable' in West Virginia. Copies of the questions asked of these two groups can be found in Appendix E for the art educators and Appendix F for the community specialists. A summary of their responses, including some exact quotes, is included in the Chart Narrative Data Analysis of Art Educator Responses for the art educators and in the Chart Narrative Data Analysis of Community Specialist Responses.

\section{Methodology (Qualitative Analysis)}

For the purpose of this study, I analyzed the potential for integrating place-based education into K-12 schools and sought feedback and responses from three West Virginia art educators and three West Virginia community specialists. The qualitative study of the narrative data provided gave insight on the interviewees' teaching practices and community goals. The interviewees were mailed consent forms which included brief survey questions. These surveys asked questions concerning teaching experience, work experience, educational interests, and 
organization memberships. Sample interview consent forms can be found in Appendix A and Appendix C. Finally, telephone interviews were conducted with the participants and responses to their questionnaires recorded. Before the analysis of the narrative data, what follows is a description of the participants gathered from the consent forms.

\section{Description of Survey Participants}

Art Educator 1 is a native of the greater Morgantown area. He has been teaching visual art education in West Virginia for more than fifteen years. During these fifteen years, he has had the opportunity to work with both middle and high school grade levels. Currently he is a high school visual art educator and artist who is interested in art that addresses social issues such as environmentalism, consumerism, and gender/racial equality. He is a member of the National Art Education Association, thus his students are able to participate in the National Art Honorary Society.

Art Educator 2 is also a highly experienced art teacher, with a Masters degree in Art. She is a talented artist as well as a teacher, and is currently working as a K-5 visual art educator. The last ten of her fifteen years teaching experience have been in West Virginia teaching at the elementary and middle school level. Interests for this educator include contemporary artists such as Andy Goldsworthy and social issues such as his environmental land sculptures. Educator 2 is also a member of the American Federation for Teachers Union.

Art Educator 3 has been working as an art educator for over fifteen years, and is currently teaching at a local middle school. She has a Masters Degree in Education and Bachelors degree in Fine Arts, as a Studio Artist. This teacher has had teaching experience in several different schools, working with both middle and high school level students. Educator 3 is a member of 
the National Art Education Association and her work as an educator was recently published in an art education magazine.

Community Specialist 1 has been working at a community organization for five years. She is not a native of West Virginia, and has not worked for any other community-based organizations similar to her current position. Her current organization is active in supporting the local community organizing events and meetings for environmental remediation efforts for community watersheds. She has a variety of duties within the organization mainly helping teach youth about the importance of environmental education and science.

Community Specialist 2 is a native to West Virginia. She is also an artist with a Bachelors Degree in Fine Arts. She works as a Summer Program Director for an elementary school. She believes very strongly in the philosophy and practices of her organization. Her own children participate in the summer program.

Community Specialist 3 has taught as an art educator in West Virginia for over fifteen years. Prior to her current position which facilitates community art projects, she worked as a teacher at a private high school in the state. She remains very active with the art education circle, and continues to attend local art educator meetings. Community Specialist 3 keeps in contact with local art teachers and has experience working with public school art educators on community-based art projects.

\section{Analysis of Narrative Data}

As explained in the research design section in Chapter One, I created a list of categories that seemed to capture the main themes addressed in the interview responses. Each category was assigned an abbreviation code. 
NARRATIVE DATA CATEGORIES:

- Benefits to Place-Based Education $(B E)$

- Environmental Art and Education (EA)

- West Virginia Content Standards and Objectives (CSO)

- Example Projects (EP)

- Community Outreach $(\mathrm{CO})$

- Program Classes (Community) $(P C)$

- System Limitations $(S L)$

- Field Studies $(F S)$

- School Policy $(S P)$

- Education Collaborations (EC)

The questionnaire responses were categorized as positive (+) if an answer was in some way supportive to place-based art education practices. A response was deemed negative (-) if in some way the answer undermined place-based art education practices. A response was categorized as neutral $(\mathrm{N})$ if the answer was impartial, without a strong support for or against place-based practices. For example, a neutral response could mean that an interviewee response was merely stating facts such as details of an example project or a school's fieldtrip policy.

Once evaluated as positive, negative or neutral, the responses were then summarized in two charts - one for the art educators and one for the community specialists. Each chart is followed by a summary of the findings of narrative analyses, as well as representative responses indicating either the positive, negative, or neutral nature to the response.

\section{Narrative Data Analysis of Art Educator Responses}

\begin{tabular}{|c|c|c|c|c|}
\hline $\begin{array}{c}\text { Question } \\
\text { Number (\#): }\end{array}$ & $\begin{array}{c}\text { Art Educator 1 } \\
\text { (AE 1) }\end{array}$ & $\begin{array}{c}\text { Art Educator 2 } \\
\text { (AE 2) }\end{array}$ & $\begin{array}{c}\text { Art Educator 3 } \\
\text { (AE 3) }\end{array}$ & TOTAL: \\
\hline 1 & $\mathrm{~N}$ & $\mathrm{~N}$ & $\mathrm{~N}$ & \\
\hline 2 & + & + & + & \\
\hline 3 & - & - & $\mathrm{N}$ & \\
\hline 4 & - & $\mathrm{N}$ & $\mathrm{N}$ & \\
\hline 5 & $\mathrm{~N}$ & - & $\mathrm{N}$ & \\
\hline
\end{tabular}




\begin{tabular}{|c|c|c|c|c|}
\hline 6 & - & $\mathrm{N}$ & - & \\
\hline 7 & + & + & + & \\
\hline 8 & $\mathrm{~N}$ & $\mathrm{~N}$ & $\mathrm{~N}$ & \\
\hline 9 & - & $\mathrm{N}$ & $\mathrm{N}$ & \\
\hline 10 & - & - & + & \\
\hline 11 & $\mathrm{~N}$ & + & - & \\
\hline 12 & + & + & + & \\
\hline 13 & + & - & - & \\
\hline 14 & + & $\mathrm{N}$ & + & \\
\hline 15 & $\mathrm{~N}$ & - & $\mathrm{N}$ & \\
\hline 16 & + & + & $\mathrm{N}$ & \\
\hline 17 & + & $\mathrm{N}$ & + & \\
\hline 18 & $\mathrm{~N}$ & + & + & \\
\hline Totals: & & 6 & & \\
\hline Positive & 7 & 5 & 7 & 20 \\
\hline Negative & 5 & 7 & 8 & \\
\hline Neutral & 6 & & & \\
\hline
\end{tabular}

- $37 \%$ of the Art Educator responses were rated as favorable for integrating place-based art education in West Virginia.

- $24 \%$ of the Art Educators responses were rated as unfavorable for integrating placebased art education in West Virginia.

- $\quad 39 \%$ of the Art Educators responses were rated as neutral, without a strong support for or against place-based art education practices in West Virginia.

A qualitative analysis of each of the eighteen Art Educators questions follows.

Question 1.) Can you think of a lesson that you have done with your students that is West Virginia-based such as the example I gave?

Summary of Positive Responses:

- N/A

Summary of Negative Responses:

- N/A 


\section{Summary of Neutral Responses:}

- My students do a printmaking lesson based on the artwork of artist Blanche Lazzell, born in Monongalia County and from West Virginia. Lazzell was part of the modern art movement and created line cut prints, which were run through the press, and then hand colored with watercolor paints... [AE 1]

- ... we had a visiting artist (who painted landscapes of West Virginia) come in and did a demonstration for the school in the gym. Then the students painted local landscapes using watercolor paints. [AE 2]

- ...one example would be CD mosaics that I have students make using painted and broken CDs... The themes have been myths, legends, West Virginia landscapes, and West Virginia tales. I had students make tile designs of the "moth man" and the New River Gorge Bridge, I also had a students do Canaan Valley. [AE 3]

Question 2.) If no, what about an environmental project or lesson? For example: Talking to students about recycling and using recycled materials to make artworks.

\section{Summary of Positive Responses:}

- Yes, of course we do things like that in our lessons...I had a student teacher who did a project with the students where they designed and built a city using old, recycled, electronics and computers... [AE 1]

- Yes, I have done a lot of recycling and environmental projects. Our classroom uses a lot of recycled materials to make art. Every day, students bring me cardboard tubes, yogurt containers, bottle caps, and cardboard that could be used for making art... [AE 2]

- I always tell my students that there is never any trash in the art room; there are always opportunities to use new and different materials to work with....My CD tile mosaics lesson plan...Also, in general our room just uses lots of recycled materials like cardboard and newspapers. [AE 3]

\section{Summary of Negative Responses:}

- N/A

\section{Summary of Neutral Responses:}

- N/A 
Question 3.) Have you ever taken a class on a fieldtrip to a local community organization, to help students learn more about a specific project?

Summary of Positive Responses:

- N/A

\section{Summary of Negative Responses:}

- By the time I could get approval then the project would be complete, trips need about two months of prep time. [AE 1]

- In an elementary public school, here, it is logistically almost impossible to take students on an art fieldtrip. It means dealing with buses and it's up to the classroom teachers that decide where that grade will go. There is only one fieldtrip scheduled for the year... [AE 2]

\section{Summary of Neutral Responses:}

- For this school, I did have my students visit Dorsey's Knob as a homework assignment. I required that they go in groups and to see the community tile mural project [that I was part of], and then take pictures in front of the mural as proof that they were there. This was to help inspire them for their CD mosaic designs. [AE 3]

Question 4.) Do you ever take students outside to sketch, on site?

\section{Summary of Positive Responses:}

- N/A

\section{Summary of Negative Responses:}

- I used to take my students outside occasionally, particularly with my smaller classes... However, sometimes...they get distracted or lack the motivation to work. They sometimes think that going outside is more just to be out of the classroom and relax/socialize rather than work. [AE 1]

\section{Summary of Neutral Responses:}

- ...there is no fence on the playground right now, and it's a pretty busy road that the school is on ...so I wouldn't want to take students out there for art. [AE 2]

- ...I have taken kids to sketch outside at Coopers Rock... Another time I took my 
students outside to draw trees so they could observe trees from life and then draw what they see. [AE 3]

Question 5.) Have there been any projects or lessons that you've done with students, where they used gathered materials from outside and/or created artwork with found objects?

\section{Summary of Positive Responses:}

- N/A

\section{Summary of Negative Responses:}

- For these projects I collected the materials on my own time, it's a safety issue to have young kids outside wandering and collecting materials. Also, there are no trees on our school ground so there aren't a lot of resources to gather for creating art. [AE 2]

\section{Summary of Neutral Responses:}

- My classes haven't done any specific projects with that but I have had students use found materials that they incorporate into their artwork. [AE 1]

- My students use natural materials in their work sometimes, for example students collected rocks to help balance out their bobble head sculptures... [AE 3]

Question 6.) Do you think there are limitations to West Virginia based lessons, like the project example that I provided?

\section{Summary of Positive Responses:}

- N/A

\section{Summary of Negative Responses:}

- ...In order to do that you would have to work your tail off. Your time as a teacher is limited, and the extra time that something like this would take out of the classroom would be extensive. [AE 1] 
- It's a little difficult in the middle schools to organize out of school projects because students can't drive yet and afterschool organizations can be tricky. The limitations are getting funding and organizing these projects, the spring glass mosaic project was nice because the community specialist brought the project to my classroom. I welcome artists/projects that can be brought here and presented in class. [AE 3]

\section{Summary of Neutral Responses:}

- ...This is all 'do-able' but it just takes more planning, but that's everywhere not just here in West Virginia... One solution to that could be seeing all the grades in one day... [AE 2]

Question 7.) Do you think your students would be more engaged and motivated to do projects coupled with a fieldtrip or community outing?

\section{Summary of Positive Responses:}

- Yeah, something that translates outside of class might strike a chord with a lot of the students. I think that upper level school students would be motivated... [AE 1]

- Absolutely, any time they go on a fieldtrip the students get really excited to be outside of the school and doing hands-on activities. Experiencing things out of school is a good break from worksheets, and they do a lot of worksheets. [AE 2]

- ...students are motivated anyway but I have noticed that after we go on fieldtrips and see exhibits they get more engaged and it really positively affects their artwork. They are typically enthusiastic about art history and seem to work a little harder. [AE 3]

\section{Summary of Negative Responses:}

- N/A

\section{Summary of Neutral Responses:}

- N/A

Question 8.) Do you typically integrate new lessons into your curricula each year? What agendas do you consider when planning for an upcoming school year? 


\section{Summary of Positive Responses:}

- N/A

\section{Summary of Negative Responses:}

- N/A

\section{Summary of Neutral Responses:}

- Materials and what classes I am actually teaching tend to motivate my planning, also the make-up of the class. I have to think about how many students have modifications and frankly how bored I am with a project... it makes you wonder how many ways can you really teach the same material. [AE 1]

- I don't like to do the same thing each year because it gets pretty monotonous. Some of the lessons that I find to be really successful I rotate and reuse. I do all my ordering over the summer...In terms of our budget, here in Mon County, it's more than most rural counties in West Virginia... [AE 2]

- Yes, I get bored with the same projects over and over...It's important for an art teacher to stay current, to see exhibits because it motivates and keeps the teacher renewed. My teaching style is always evolving, I like exploring different materials and trying new materials, putting twists on projects... [AE 3]

Question 9.) Have you ever done a collaborative, multidisciplinary project? Can you give me an example of one that you have done?

\section{Summary of Positive Responses:}

- N/A

\section{Summary of Negative Responses:}

- A couple times I have tried to do projects with other teachers and what happens is that these other teachers see a collaboration with the art department as a way to push the project into the arts room so they can get an extra free period for planning ... but I didn't think these projects really utilized my skills as an art teacher. [AE 1] 


\section{Summary of Neutral Responses:}

- ...it is tough to do particularly having the schedule the way it is, it's a lot easier to plan with grades when we have all the students in one grade on the same day...I did a collaborative project with $1^{\text {st }}$ graders and their homeroom teacher. They learned about the three parts of insects so we had students make and design their own bugs using clay... [AE 2]

- Yes, I have done collaborative projects with the theatre department, I taught about the history of mask making in the theatre and students made masks to use for a performance... I should note too that it's important to integrate West Virginia culture as well as teaching multicultural lessons so students become aware of and begin to appreciate different cultures as including the local culture here in Morgantown. [AE 3]

Question 10.) Have you worked with the community/community members on an art lesson or project?

\section{Summary of Positive Responses:}

- I worked on the community glass mosaics this past spring and for that lesson a community specialist came into the classroom, but I have also had lots of local artists come in and present their work... I really think the great thing about the glass tile mosaic project was that it brought community specialists into my classroom and allowed them to take over to teach their lesson within the school. [AE 3]

\section{Summary of Negative Responses:}

- We used to do a monthly revolving art exhibit, where we found local businesses that would display the students works. This required a lot of time and work, particularly installing these works... Often these projects start off with a great idea but participants don't always have enough foresight to see all the work that a project will entail and thus lose the momentum. [AE 1]

- It has been about 4 or five years but I did work on the Isaiah Zagar inspired community tile mural project... This is something that I did as an educator during my summer and some of the student's ceramic works were used in that mural...I have wanted to do a mural with the kids but it's hard with kids who are really young. [AE 2]

\section{Summary of Neutral Responses:}

- N/A 
Question 11.) What, in your opinion, are the limitations of doing a collaborative project, with other teachers, organizations, or community members?

\section{Summary of Positive Responses:}

- I have been working on an empty bowls project, students get to decorate a ceramic bowl that gets glazed and then sold to the community to help raise money for charity, the homeless. This project was a huge deal and took a lot of time and planning. The money was the most challenging part, not impossible but it just takes time finding the funding and support. [AE 2]

\section{Summary of Negative Responses:}

- In all honesty, the collaborative projects are much easier to plan working with the high school grade levels just because students have a higher skill level and are able to work on bigger projects. The limitations are a prime factor, it seemed like there was a little more time to make collaborations at the high school level as opposed to middle school... [AE 3]

\section{Summary of Neutral Responses:}

- I think first and foremost time, if it involves money where does the funding come from. Also, if all parties are aware of what the project entails and are people willing to do their share of the work. [AE 1]

Question 12.) What do you think the limitations are for creating West Virginia-based projects that still meet content standards and goals? 


\section{Summary of Positive Responses:}

- No there is enough out there and with the influx of people and influences; there is definitely a means for creating West Virginia-based lessons. There is enough history in West Virginia that there shouldn't be a problem [covering local arts]. There is a diversity of people moving to the area which helps create opportunities for learning. [AE 3]

- ...the CSOs are open enough and there are so many different lessons you can use for them. CSOs aren't too specific in the sense that they are limiting. [AE 2]

- I don't think there are limitations, there is a lot to draw from in West Virginia and I love to teach students about the folktales and the beautiful landscapes... It is especially helpful with the use of the internet because students can look up and find out more information about West Virginia. [AE 3]

\section{Summary of Negative Responses:}

- N/A

\section{Summary of Neutral Responses:}

- N/A

Question 13.) Does your school have parents who are actively involved with the school, volunteers to help out in the art room? Would West Virginia based lessons be easier if you had more parental support?

\section{Summary of Positive Responses:}

- No parent volunteers specifically have come to the art room. In the past we have had parents who get involved and support the school and other school subjects. It would be great if parents who are business owners and community specialists could give support and could be involved in our arts program ...they could display our artwork at their work place so that the community is seeing students work. [AE 1]

- Yes, we have a list of parent volunteers and there are people who will come in and help but a lot of parents work. Parents work and so their schedule is limited and that makes it difficult to find volunteers for more than an hour a week. We are very lucky that we have parents who have the time to come in. There are lots of counties in West Virginia that probably have parents who work all the time. [AE 2]

- I have had parents come in and help out some, but also parents who are artists 


$\begin{aligned} & \text { have come to present their work... They help out by sending in supplies and } \\ & \text { materials and for example taking students to see the Dorsey's Knob mural after } \\ & \text { school. [AE 3] }\end{aligned}$
Summary of Negative Responses:
- N/A
Summary of Neutral Responses:
N/A

Question 14.) Do you think it's reasonable to incorporate one or two West Virginia based projects into your curricula each school year? How do you think your students would respond to these lessons?

\section{Summary of Positive Responses:}

- No there is nothing unreasonable about that and as far as the CSOs there's no limitations because they are open enough. It does help open students eyes if lessons go beyond the classroom. I think probably that overall most students would be fairly engaged... [AE 1]

- I definitely think it's reasonable and it's good to get students involved, even just having them look at local scenery. It's a natural thing for my class because I have always talked about West Virginia history and our local community. [AE 3]

\section{Summary of Negative Responses:}

- N/A

\section{Summary of Neutral Responses:}

- I haven't done a West Virginia-based lesson that I can think of but a few years ago my fourth graders did a program for West Virginia Sings. This is a performance that is put on for parents, but my fourth grade students made a backdrop for the show. The backdrop included a black bear, a mountaineer, rhododendrons, and a cardinal...Mostly it's the CSOs for fourth grade and kindergarten which focus on West Virginia history. [AE 2] 
Question 15.) Can you tell me a little about the school's policy on fieldtrips? And whether the school ever helps to fund fieldtrips?

Summary of Positive Responses:

- N/A

\section{Summary of Negative Responses:}

- The policy on fieldtrips has gotten stricter, and I don't think that I would even be able to do a fieldtrip with students...Fieldtrips can be a lot because teachers barely have time to cover what they need to in one day so it's tough to get around that lesson time. [AE 2]

\section{Summary of Neutral Responses:}

- The school county policy for fieldtrip approval must be two weeks in advance and the board (who approves trips) meets every other week. If it's an in county trip the bus should be free, but I'm not sure if that rule applies to the High school as well. If the county doesn't provide free transportation for your trip then you have to raise money and plan transportation yourself. [AE 1]

- We have funds that you can request or you can also ask students to bring in money to help out. I haven't done that much at this school; the school kind of wants the fieldtrips to be done around the same time frame. The policy isn't against fieldtrips they are just harder to squeeze in. [AE 3]

Question 16.) What do you hope for your students to gain and learn from your art classes in the long term?

\section{Summary of Positive Responses:}

- I want students to see that there is a bigger connection in what they learn in the studio process. That they don't need to just be an artist, they can take these skills and apply them elsewhere. I want them to learn critical thinking skill and to have a better appreciation for what they see, understanding aesthetics in a more broad appreciation. [AE 1]

- And I think it's important to get students to do higher level thinking, experiential, hands-on, creative problem solving where they use their imagination. Art teachers have an important job helping kids to be creative. [AE 2] 


\section{Summary of Negative Responses:}

- N/A

\section{Summary of Neutral Responses:}

- I want students to know that the arts can always be part of their life in some form or another...The skills they learn are hobbies or can help them to see the world in a broader way. I think that students culturally experience a lot just from learning about art history... [AE 3]

Question 17.) Do you think the visual arts are in some way a reflection of the artist's surroundings?

\section{Summary of Positive Responses:}

- Definitely, I think that's the number one influence, particularly studying what materials artists can get and what they use, what is going on politically where they live. These all play a major role in what the artist is making. [AE 1]

- I think that an artist's surrounding can be an inspiration for creating art but it's not one specific thing. I think art and inspiration can go beyond that as well...[AE 3]

\section{Summary of Negative Responses:}

- N/A

\section{Summary of Neutral Responses:}

- My favorite thing to do is pottery and I'm not sure if that's really a reflection of my surroundings. I think it's really more dependent on the artist. [AE 2]

Question 18.) Would discussing artworks which reflect an artist's cultural and environmental background be something that you're interested in exploring and teaching your students?

\section{Summary of Positive Responses:}

- Yes, I try to do this a lot and also our school has a multicultural plan. I did a multicultural lesson recently, teaching students about the Pacific Northwestern Indians and they made totem poles out of cardboards tubes. We talked about the Indians culture...After the story we talked as a class about the artwork of these Indians. Students really love to discuss artwork... [AE 2]

- I think I have done a lot of that and I'm always open to learning more about 


different artists. Sometimes I think my students teach me, they really bring a lot of
themselves into their artwork. [AE 3]
- N/A
Summary of Negative Responses:
-..I offer an art appreciation class which incorporates studies of the humanities and looks
at the different art styles, time periods, and locations/cultures of artists and what
happened during that time. They also make artwork, creating project-based on the style of
art that the students are learning about. [AE 1]

Narrative Data Analysis of Community Specialist Responses

\begin{tabular}{|c|c|c|c|c|}
\hline $\begin{array}{l}\text { Question } \\
\text { Number (\#): }\end{array}$ & $\begin{array}{l}\text { Community } \\
\text { Specialist } 1 \\
\text { (CS 1) }\end{array}$ & $\begin{array}{l}\text { Community } \\
\text { Specialist } 2 \\
\text { (CS 2) }\end{array}$ & $\begin{array}{l}\text { Community } \\
\text { Specialist } 3 \\
\text { (CS 3) }\end{array}$ & TOTAL: \\
\hline 1 & + & $\mathbf{N}$ & $\mathbf{N}$ & \\
\hline 2 & + & + & + & \\
\hline 3 & + & + & + & \\
\hline 4 & + & $\mathbf{N}$ & + & \\
\hline 5 & + & + & + & \\
\hline 6 & - & $\mathbf{N}$ & + & \\
\hline 7 & + & + & - & \\
\hline 8 & + & + & + & \\
\hline \multicolumn{5}{|l|}{ Total: } \\
\hline Positive & 7 & 5 & 6 & 18 \\
\hline Negative & 1 & 0 & 1 & 2 \\
\hline Neutral & 0 & 3 & 1 & 4 \\
\hline
\end{tabular}

- $75 \%$ of the Community Specialists responses have been rated as favorable for collaborating on place-based art projects with schools in West Virginia. 
- $8 \%$ of the Community Specialists responses have been rated as unfavorable for collaborating on place-based art projects with schools in West Virginia.

- $\quad 17 \%$ of the Community Specialists responses have been rated as neutral, without a strong support for or against collaborations on place-based art projects with schools in West Virginia.

A qualitative analysis of each of the eight Community Specialist questions follows.

Question 1.) Can you tell me about any projects or classes that you offer through your program that is West Virginia-based like the example I gave?

\section{Summary of Positive Responses:}

- We have done several projects of this nature with our Youth Advisory Board (YAB) and community partners. Working with BOPARC's Arts in the Park program we designed, created, and installed glass mosaics in the Friends of Deckers Creek Outdoor Learning Park...YAB members researched information on these creatures including their life-history, habitat preferences, and where they can be found in the Deckers Creek watershed. These reports were turned into posters mounted on the backs of the mosaic pieces. YAB members also helped with the installation of native plant gardens, artistic rock borders, signage, pavilion, and benches in the Outdoor Learning Park... We also painted three stream-inspired murals in the community...YAB members helped to design and paint both of these murals learning about the importance of watersheds, aquatic wildlife, and community beautification... [CS 1]

\section{Summary of Negative Responses:}

- N/A

\section{Summary of Neutral Responses:}

- We did a summer project last year with West Run Water Association and Friends of Decker's Creek. For this project students learned about West Virginia stream beds and then the students got to help design and paint a mural on one of Morgantown Learning Academy's school fences. The mural was themed West Virginia streams; our program here really does a lot with community service. [CS 2]

- We have done quite a few community projects; for the past ten years Morgantown's summer program, Arts in the Parks, has focused the community on children's painted murals. Each summer we have done a mural with a different theme, for example one summer we had West Virginia 
Literature and another year it was West Virginia Native Animals and Plants. For the West Virginia Literature mural, three West Virginia writers came to our program space and talked to students. Then students did their own creative writing and their writings became the inspiration and design for a three panel mural that is on the exterior of the Old Chamber of Commerce building in downtown Morgantown. [CS 3]

Question 2.) Could you see any of the projects or classes that you offer through your program as part of a public school curriculum? (In other words, do you think a public school could do the same projects and/or lessons as your program?

\section{Summary of Positive Responses:}

- Yes, for example I can see art and science teachers teaming up to do riverbased projects where students learn about watersheds, how to sample for pollutants, and do stream-related art projects based on their findings. [CS 1]

- I think the lessons associated with these programs and workshops could easily be incorporated into school curricula. For example students could learn a full lesson on the process of making tile mosaics, or on researching and making different cultural foods for a social studies international lesson. [CS 2]

- I have been in close contact with the art teachers in this community; I talk with them and attend their Art Education meetings. Some of the Monongalia county public schools here have been involved in our big current mixed media tile project entitled "A Celebration of Diversity." For this project I go into the schools to help facilitate the project, bringing along supplies and helping to instruct the first few classes. In this way, I am bringing the project... [CS 3]

\section{Summary of Negative Responses:}

- N/A

\section{Summary of Neutral Responses:}

- N/A 
Question 3.) Are you at all familiar with West Virginia state content standards? Has your program ever followed, or researched, West Virginia's Board of Education content standards and objectives for the teaching?

\section{Summary of Positive Responses:}

- Yes I am familiar. We do not follow the CSOs for YAB projects, but we do try to work them into our education projects with local schools. For instance, $Y A B$ will be going into High School classrooms this spring through our Youth Watershed Bill of Rights project to teach students about watersheds, stream pollutants, how to use water monitoring probes, etc. The students will then get equipment to sample local streams for 1-2 weeks and bring their data back to map and analyze. [CS 1]

- We don't look at CSOs as much for our summer programs, but our projects definitely have an educational focus and do follow West Virginia content standards. There is a variety of topics that we cover in our summer programs and workshops but all of these are very experiential and hands-on. Because our activities are more experiential, students seem to learn more and really get interested in learning; we really want to make education fun. I have noticed that our students are exceeding the CSOs; they are engaged with learning and doing great. [CS 2]

- I taught as a classroom teacher for twenty years so I am very familiar with the CSOs. I wouldn't say that projects like the 'Celebration of Diversity' set out with the CSOs in mind but it's almost impossible not to meet them. [CS 3]

\section{Summary of Negative Responses:}

- N/A

\section{Summary of Neutral Responses:}

- N/A

Question 4.) What do you want students to take away from their experience and involvement in your program? 


\section{Summary of Positive Responses:}

- We want youth to become more familiar and engaged with their local environment in general and with streams in particular, to become better environmental stewards, civically engaged, and to feel important within their community. We also seek to improve their science inquiry, leadership, public speaking, and team working skills. [CS 1]

- I want students to be part of something that's bigger than them, and involved in their community. These projects are about building students' sense of place and pride in their community. Art can enrich a community and help make it healthy. [CS 3]

\section{Summary of Negative Responses:}

- N/A

\section{Summary of Neutral Responses:}

- It's a summer program so we don't want to have quite as much structure as the school year, we try to provide experiences that are fun and engage children in learning. Also important is for us to incorporate activities that help maintain what is learned in the school year, because a lot gets lost in the summer months... [CS 2]

Question 5.) Have you worked on any collaborative projects/classes with local West Virginia schools? Can you give me an example of a collaboration project that your program has participated in, within the last two years?

\section{Summary of Positive Responses:}

- The BOPARC Arts in the Park collaboration is a good example. And we are going to be working with Morgantown High School, University High School, and Preston High School this spring on the Youth Watershed Bill of Rights project described above. [CS 1]

- Our school and summer programs are very hands-on, we have a lot of community speakers come into the school such as West Run Watershed Association, WOW pottery factory, Stonewall Jackson Resort, Valley Ridge Farms, and the West Virginia Raptor Rehabilitation Center... It's really hard in the summer to plan and do fieldtrips because of transportation so we try to bring those experiences here. We have an outdoor classroom which is a great space for students to be able to be lean and experience the outdoors. [CS 2]

- We are currently working on two big collaborative projects, one is a ceramic 
and glass mural that will be displayed down by the riverfront in

Morgantown... We are working with the community, different schools and civic organizations, to make individual leaves that will be collectively displayed to form one large tree. This project is called "A Celebration of Diversity" and the idea of this project is basically "peace" through art because the tree takes on the shape of a globe... Our program is also working with an elementary school in Fiji...Students in Morgantown are drawing prism colored leaves. These leaves will be combined with the drawings that students from Fiji create to make one big collaborative mural that will be displayed within the Fiji school building...The leaves that students are creating either depict imagery of what is important to students or what they wish for the world. [CS 3]

\section{Summary of Negative Responses:}

- N/A

\section{Summary of Neutral Responses:}

- N/A

Question 6.) What do you think are limitations to your program collaborating with local school?

\section{Summary of Positive Responses:}

- All the normal problems, mostly just space and budget but theoretically there shouldn't really be any other limitations. In fact I think more collaboration should be done with the schools and community. [CS 3]

\section{Summary of Negative Responses:}

- Scheduling and finding teachers willing to collaborate with. [CS 1]

\section{Summary of Neutral Responses:}

- Our program is already affiliated with our school, we do a lot of student collaborations and peer-teaching in our school program... With our summer program, for instructor to student ratio and the sign-up is by week, so I would say that it's a great deal for parents. We need to have our schedules set by May $5^{\text {th }}$, so then parents are contractually bound to whatever they sign their students up for but prior to that our scheduling is pretty open. [CS 2] 
Question 7.) In your opinion, do you think working with local schools is beneficial to the community? If yes, in what way?

\section{Summary of Positive Responses:}

- Absolutely! It's a great way to get students involved with their local nonprofit and community. It gives them a better sense of place and community. [CS 1]

- ...We have a lot of community outreach projects that are part of our school curricula because we want the students to understand more about civic duties and how to we can take care of each other. We have campus food drives, clean-up days, and a small garden that our summer program gets involved in. We want to get children to be a part of their own space. [CS 2]

\section{Summary of Negative Responses:}

- ...it seems there is more of an emphasis and exposure to sports particularly at the high school level, but not so much for the arts in Morgantown. I think sometimes art gets lost in the shuffle, but getting students engaged and involved in where they live is really important to the health of the community. If you look at a healthy and thriving community, they usually have public art. [CS 3]

\section{Summary of Neutral Responses:}

- N/A

Question 8.) Do you believe your program contributes to the advancement of West Virginia? If yes, in what way?

\section{Summary of Positive Responses:}

- Yes. We are educating and empowering youth who will be the future leaders of watersheds. [CS 1]

- Absolutely, I think that any time children are involved in their community that has positive effects on the states. It allows for children to experience and be exposed to education that relates to their own interests. Getting involved in the community gets students thinking that's outside the box, which is really important for making new discoveries. [CS 2]

- Absolutely, I think it benefits the kids in so many ways, it opens their eyes to new connections and possibilities, and they get a larger connection with the world. [CS 3] 
Summary of Negative Responses:

- N/A

Summary of Neutral Responses:

- N/A

\section{Study Summary and Findings}

The highest percentage of overall responses for art educators were coded as neutral because they lacked a definitive statement of support for or against place-based practices. The second highest percentage for art educators' responses was positive. Neutral responses simply relayed information such as describing projects that focused more on art history and art processes and techniques, but not necessarily on place-based lessons. For example, I asked if they ever did an art lesson in which students used naturally found materials. One educator told me about a lesson where students made bobble head dolls and used rocks from outside to weigh down the base of their sculptures. Although this lesson did use found objects in an art lesson, it was not a lesson in relation to environmental or ecological art using natural materials. Therefore this response was coded as neutral, not positive.

Even though the art educators were not asked to comment specifically on place-based education, their reactions about elements of place-based education were positive and supportive of it. Specifically, Question 16 asked what they hoped students would gain and learn from their art classes in the long-term. Some of their answers reflect the constructivist theory that says thought development may result from studies and learning that goes beyond a classroom. One educator responded, "I want them to learn critical thinking skills and to have a better appreciation for what they see, understanding aesthetics in a more broad appreciation." Another 
response was, “...it's important to get students to do higher level thinking, experiential, handson, creative problem solving where they use their imagination." Both of these answers were coded as positive.

The art educators expressed a willingness to try place-based projects however they indicated that system limitations such as student safety, school policy and budget are factors that challenge the potential for teaching place-based art education projects. The majority of responses that addressed these issues were coded as negative.

Seventy five percent of the community specialists' responses were coded as positive for collaborating on place-based art projects with schools in West Virginia. This percentage is the highest for both surveys. All three community specialists have done at least one place-based project in cooperation with a school. For example, one community specialist is currently doing a project with a school in which the students made stained glass leaves that will be incorporated into a local community mural. This specialist went into the school and helped to introduce and present the project to students.

Some of the questions asked of the community specialists were specifically focused on how they might support place-based education in the schools. Question 2 asked if they could see any of the projects that they offer through their program as part of a public school curriculum. One educator responded, "I think lessons associated with these programs and workshops could easily be incorporated into school curricula." Another response was, "Yes...I can see art and science teachers teaming up to do river based projects where students learn about watersheds."

Research on place-based education indicates that connections built between school and the community encourag students to become active citizens. Community specialists' responses 
indicated that their programs contribute to the advancement of the community. One specialist said, "We are educating and empowering youth who will be the future leaders of watersheds." Another said, "It opens [students'] eyes to new connections and possibilities...they get a larger connection with the world." Both of these responses were coded as positive.

The second highest percentages of overall responses were coded as neutral, without a strong support for or against collaborations on place-based art projects with schools in West Virginia. Neutral responses simply described project collaborations such as working with a summer arts program to "design, create, and install a community art mosaic." Community specialist two responded to Questions 4 and 6 neutrally in reference to collaborations with local schools because her program is embedded in a school.

The lowest percentage of overall responses were coded negative, as unfavorable for collaborating on place-based art projects with schools in West Virginia. The three issues that were mentioned as limitations were funding, finding teachers to collaborate with in the schools, and promoting art when sports has a higher emphasis in the schools.

OVERVIEW OF RESPONSES

\begin{tabular}{|c|c|c|}
\hline & Art Educators & Community Specialists \\
\hline Positive & $37 \%$ & $75 \%$ \\
\hline Negative & $24 \%$ & $8 \%$ \\
& & \\
\hline Neutral & $39 \%$ & $17 \%$ \\
& & \\
\hline
\end{tabular}

Based on the chart above, it is obvious that the community specialists are more positive in support of place-based education. In terms of the art educators, it appears that they are more 
affected by negative and neutral factors $(63 \%)$ that would prohibit them from integrating placebased education practices. Whereas, the community specialists are more (75\%) in favor of place-based education practices.

\section{Conclusion}

My overall conclusion is that for art educators to most successfully incorporate place-based lessons in their curricula, community specialists should assume a proactive role to provide support to school programs. From both my research and the interviews I conducted, I have drawn up a listing of some specific suggestions for the types of support they could provide:

1. In my research, I learned about numerous project and lesson collaborations offered by various community programs in West Virginia which would be valuable to art educators. I assembled a listing of these programs and attached the listing as Appendix G. My hope is that educators will use these resources for support and assistance in teaching placebased lessons. Some of the resources would also provide opportunities for service learning projects within the community.

The outdoor painted murals in Figure 6 and Figure 7 below are examples of community art projects that were done in Morgantown, West Virginia. The murals were designed and painted by the Friends of Decker's Creek Youth Advisory Board. This project is an example of a possible collaboration with public school visual arts.

Another successful collaborative project was the paper-mache maple tree sculpture lesson that Stifel Schrader Environmental Education Center did with a local elementary school. This project was described in detail in chapter 3 . 


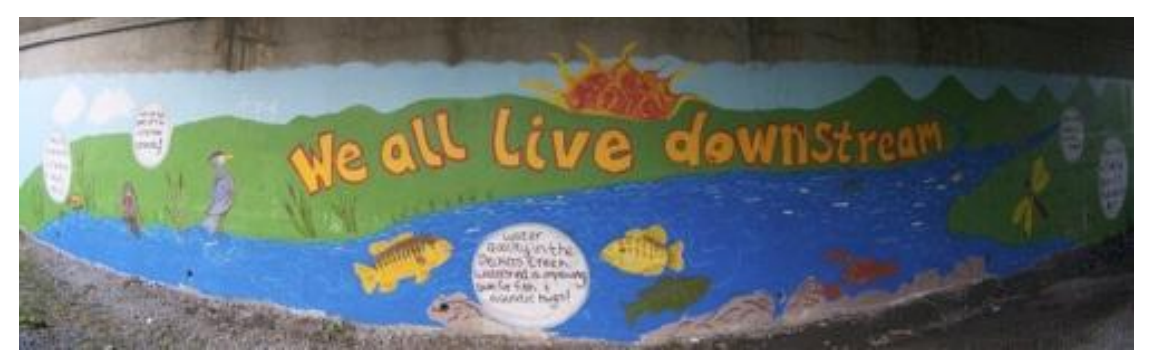

Figure 6- Community Art with an Environmental Message (Above) - Youth, who are active participants in the Friends of Decker's Creek Community Organization, painted this outdoor mural. The mural's message conveys how we are all connected to our local environments.

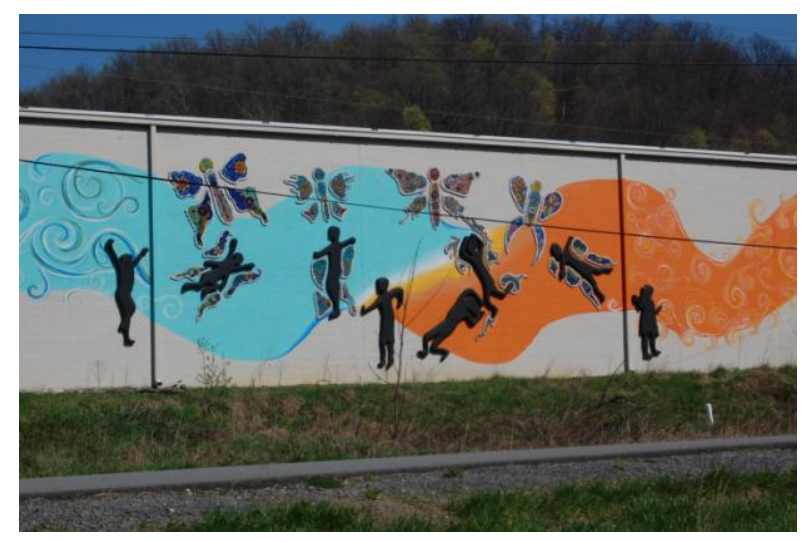

Figure 7- Friends of Decker's Creek Mural (Above) - Members of Friends of Decker's Youth Advisory Board worked collaboratively to develop this community tile mosaic and painted mural for Morgantown residents. This display can be seen from the Morgantown rail trail, located near the Friends of Decker's Creek outdoor learning center.

2. Community specialists could offer to come into the schools to co-teach place-based lessons. A successful example of this type of co-teaching was carried out by Community Specialist 3 with her community arts glass mosaic projects. She brought the materials and presentations to local schools. She indicated that the project was well received, and it was able to take place within the confines of school policy, budget, and art educators' schedules.

3. Community specialists could reach out more assertively to art educators contacting them with opportunities for funding and projects. For example, in an interview with the Stifle Visual Arts Program the interviewee stated "any funding that is left over from our budget 
is left for us to provide to the schools. Sometimes the program will match half of the funding needed (Leeche, 2012).”

4. When asked in interviews whether West Virginia based lessons follow content standards and could be incorporated into school curricula, particularly in the arts, all the community specialists answered in the affirmative. Because of my strong belief in the benefits of place-based lessons, I created three visual arts lesson plans for West Virginia teachers. The lessons are targeted for three grade levels (elementary, middle, and high school), however each lesson could be adapted and modified to meet the West Virginia Content Standards and Objectives of any grade level. I made a sample work for each project and included a picture of the work in the lesson plan. Having personally created and made the artwork for these lessons, I am convinced that the lessons are controllable and enjoyable projects that could be done for any grade level in a visual arts classroom. These three lesson plans can be found in Appendix H.

5. One of the benefits of place-based education is that students become actively involved in their communities. Community specialists can provide guest speakers to talk about environmental issues, local culture, and community arts.

6. Place-based lessons expose students to career opportunities in fields such as watershed management, recycling, land reclamation, and cultural preservation. I talked with a community specialist at the Mountain Institute's Randolph County Outdoor Education Program who said the program's goal is to "show students what kinds of professions are possible while still living in West Virginia (King, 2012)." Career building is part of what a teacher does to help students grow. 
It is my hope that this project might contribute to early research conducted in regards to the field of place-based art education in public education. I believe strongly in place-based art education practices and their potential to inspire and engage students in learning and community service efforts.

\section{Recommendations for Further Studies}

Although there is significant research and information in regards to place-based education, there is still a limited amount of research specifically on place-based art education. Additional project-based research needs to be conducted in the schools.

1. A researcher could teach a place-based art lesson within a school and create a case study that measures and analyzes the student subjects' responses. This study's research and examination of the potential for place-based art education to be integrated into K-12 schools in West Virginia, has focused attention on art educators and community specialists.

2. This study is thus limited in making definitive statements with regard to student engagement, academic performance, and interest in visual arts curricula and place-based art lessons. A case study could allow the researcher to evaluate and measure students' responses and behaviors for learning from place-based art curricula.

3. Supplementary research could also be conducted with data analysis from a K12 school that is practicing place-based education. Such a study would collect data and survey responses from school administration representatives, general classroom teachers, and the students. Hopefully the information gathered 
would be the basis for creating a working model for successful place-based education. 


\section{BIBLIOGRAPHY}

Alexander, P. A., Schallert, D. L., \& Reynolds, R. E. (2009). What is learning anyway? A topographical perspective considered. Educational Psychologist, 44, 209 -214.

Bailey, C., \& Desai, D. (2005). Visual art and education: Engaged visions of history and community. Multicultural Perspectives, 7(1), 39-43.

Baker, D.W.(1990). "Git real": On art education and community needs. Art Education, 43(6), 41-49.

Berk, L.E (2006). Child Development (7 ${ }^{\text {th }}$ ed.). Boston: Allyn \& Bacon.

Bergstrom, J.M., \&O’Brien, L.A. (2001). Themes of discovery. Educational Leadership, 58(7), 29-33.

Blandy, D., and Hoffman, E. (1993). Toward an art education of place. Studies in Art Education, 35(1), 22-33.

Bruner, J.S. (1966). Toward a theory of instruction. New York: Norton.

Byerly, S. (2001). Linking classroom teaching to the real world learning through experiential instruction. Phi Delta Kappan, 82 (9), 697-699.

Center for Place-Based Learning and Community Engagement (n.d). Promise of Place. Retrieved from: http://www.promiseofplace.org/.

Clayton, Allen (2011). Making a difference: Friends of deckers creek. Retrieved from: http://wvubureau.wordpress.com/2011/05/01/making-a-differencefriends-of-deckers-

creek-by-chelsea-fuller/.

City of Morgantown. (2011). Climate and generalinformation. Retrieved from http://www.morgantown.com/overview.htm.

Cook, J.L, \& Cook, G. (2007). The world of children. Boston: Allyn \& Bacon.

Derry, J. (2008). Abstract rationality in education: from Vygotsky to Brandom. Studies in Philosophy \& Education, 27(1), 49-62.

Dewey, John (1934). Art as Experience. Capricorn Books: New York.

Duffin, M., Chawla, L. Sobel, D. \& PEER Associates (2005). Place-based education and academic achievement. Retrieved from http://www.seer.org/pages/research/PEEC\%202005.pdf. 
Egan, K. (1989). Memory, imagination, and learning: Connected by the story. Phi Delta Kappan, $70,455-459$.

Fettes, Mark \& Judson, Gillian (2011). Imagination and the cognitive tools of place making. The Journal of Environmental Education, 42(2), 123-135.

Freeman, K. (2000). Context as part of visual culture. Journal of Multicultural and CrossCultural Research in Art Education, 18, 31-36.

Fuller, Beth (n.d). Your Community Foundation. Retrieved from: http://www.ycfwv.org/.

Golafshani, Nahid (2003). Understanding reliability and validity in qualitative research. $A$ Qualitative Report, 8(4), 597-607.

Graham, M. A. (2007a). Exploring special places: Connecting secondary art students to their island community. Art Education, 60(3), 12-18.

Graham, M. A. (2007b). Art, ecology, and art education: Locating art education in a critical place-based pedagogy. Studies in Art Education, 48(4), 375-391.

Gruenewald, D. A. (2003). The best of both worlds: A critical pedagogy of place. Educational Researcher, 32(4), 3-15.

Hansen, Erica (2009). "Island ecology: An exploration of place in the elementary art Curriculum.” Art Education, 62 (6), 46-51.

Hicks, L. E., \& King, R. H. (2007). Confronting environmental collapse: Visual culture, art education, and environmental responsibility. Studies in Art Education, 48 (4), 332-35.

Holt, D.G., \&Willard-Holt, C. (2000). Let's get real: Students solving authentic corporate problems. Phi Delta Kappan, 82 (3), 243-246.

Hull, L. (2003). What is environmental art? Retrieved from: www.eco-art.org.

Inwood, Hilary J. (2008). At the crossroads: Situating place-based art education. Canadian Jounral of Environmental Education, 13 (1), 29-41.

Janelsins, E. (2012, February 17). Interview by M.L. Drexler [Personal Interview]. Community Specialist Interview.

Kelly, Dan (2006). Randolph county outdoor education program. Retrieved from: http://www.wvonline.com/north/rcoep/rcoep7.html.

King, C. (2012, February 3). Interview by M.L. Drexler [Personal Interview]. Community Specialist Interview. 
Lai, A. \& Ball, E.L (2002). Home is where the art is: Exploring the places people live through art education. Studies in Art Education, 44 (1), 47-66.

Lawton, Pamela Harris (2010). Hand-in-hand, Building community on common ground. Art Education, 63(6), 6-12.

Leeche, J. (2012, February 5). Interview by M.L. Drexler [Personal Interview]. Community Specialist Interview.

Lippard, L.R. (1997). The lure of the local: Senses of place in a multicentered society. New York: New Press.

Maxwell, J. A. (2005). Qualitative research design: An interactive approach. (pp. 214-253). London: Sage Publications Ltd.

McFee, J. K. (1961, 1970). Preparation for art. Belmont: CA: Wadsworth.

McFee, J. \& Degge, R.m. (1997). Art, culture, and environment: A catalyst for teaching. Belmont, CA: Wadsworth.

Nyden, Paul J. (2010). Kids poorer in southern West Virginia than the rest of the state. Retrieved from http://wvgazette.com/News/201009291025.

Ospina, Sonia (2004). Qualitative research. Sage Publications. Retrieved from http://wagner.nyu.edu/leadership/publications/files/Qualitative_Research.pdf.

Paine, S. L. West Virginia Board of Education, (2008).Title 126 legislative rule board of education title 126 legislative rule board of education (Policy 2520.12). Retrieved from website: http://wvde.state.wv.us/policies/csos.html.

Place-based Education Evaluation Collaborative (2010). The Benefits of Place-based Education: A Report from the Place-based Education Evaluation Collaborative (Second Edition). Retrieved from http://tinyurl.com/PEECBrochure.

Ruppert, Sandra (2006). Critical evidence: How the arts benefit student achievement. National Assembly of State Arts Agencies. Retrieved from: http://www.nasaa-arts.org/Publications/critical-evidence.pdf.

Sanger, M. (1997). Sense of place in education. The Journal of Environmental Education, 29(1), 4-8.

Slavin, Robert (2009). Educational psychology: Theory and practice (9 ${ }^{\text {th }}$ ed.). Upper Saddle River: Pearson.

Smith, Gregory A. (2002). Place-based education: Learning to be Where We Are. Phi Delta Kappan 83 (8), 584-594. 
David Sobel (2004). Place-based education: Connecting classrooms \& communities. Great Barrington, MA: The Orion Society.

Song, Young Imm Kang (2009). Community participatory ecological and education. International Journal of Art and Design Education. 28(1), 4-12.

Stelly, Kat (2011). Estelle elementary wetlands art project unveiled. New Orleans Net. Retrieved from http://www.nola.com/west-bank/index.ssf/2011/05/post_156.html.

Taylor-Powell, Ellen \&Renner, Marcus (2003). Program Development and Evaluation: Analyzing qualitative data. University of Wisconsin-Extension. Retrieved from: http://learningstore.uwex.edu/assets/pdfs/g3658-12.pdf.

The Mountain Institute (2010). The Appalachian Program. Retrieved from: http://www.mountain.org/appalachia.

Ulbricht, J. (2005). What is community-based art education? Art Education, 58(2), 6-12.

Wadsworth, B. (2004). Piaget's theory of cognitive and affective development $\left(5^{\text {th }}\right.$ ed.). Boston: Peason.

West Virginia Division of Culture and History (2011). Retrieved from: http://www.wvculture.org/arts/artists.html.

West Virginia University (2012). Environmental research center: Friends of deckers creek. Retrieved from: http://erc.davis.wvu.edu/projects/education/fodc.

Wilcox, R.T. (1993). Rediscovering discovery learning. In K.M. Cauley, F. Linder, \& J.H. McMillian (Eds.), Annual Editions: Educational Psychology 93/94. Guilford, CT: Dushkin.

Wood, D.J., Bruner, J.S., \& Ross, G. (1976). The role of tutoring in problem solving. Journal of Child Psychology and Psychiatry, 17, 89-100.

Yelverton, Joel \& Kelly, Marc (2010). The reauthorization of the secure rural schools \& community self-determination act. The Partnership for Rural America Campaign. Retrieved from http://www.partnershipforruralamerica.org/brochures/West_Virginia.pdf. 


\title{
APPENDIX A
}

\section{SAMPLE ART EDUCATOR INTERVIEW CONSENT FORM}

\author{
MARIE DREXLER \\ Applications of Place-Based Education in an Art Curriculum for West Virginia \\ Qualitative Study in Art Education
}

I____ agree to participate in Marie Drexler's Master's of Art paper, in partial fulfillment for her degree through West Virginia University's Art Education program.

I know that my responses will be recorded and used for publication. Responses used within this paper will be recorded, by hand, and used in a manner that my identity will not be revealed. It is ensured that my identity may not be linked through any direct associations. I am also aware that it is my right to back out of this interview process and my participation in this study can be stopped at any time.

Signature:

Date:

\section{ART EDUCATOR QUESTIONNAIRE}

What grades do you teach?

How many years have you been teaching? How many years have you taught in West Virginia schools?

How many schools have you taught visuals arts education in?

If you answered more than one for the above question, have you taught visual arts to different age levels? (Specifically Elementary, Middle, and High School)

Were you born in West Virginia?

Are you interest in social and/or environmental issues? (Example: Compositing, Recycling, Pollution) Would you write down any social and/or environmental issues which you independently research/ read up on?

Are you familiar with any artists who address social and/or environmental issues in their artwork? If yes, could write artist names or a condensed description of an artwork?

Are you a member of NAEA, or any other education organization? If yes, please provide the names of these education organizations. 


\title{
APPENDIX B
}

\section{SAMPLE ART EDUCATOR INTERVIEW QUESTIONNAIRE}

\author{
MARIE DREXLER
}

Applications of Place-Based Education in an Art Curriculum for West Virginia

Qualitative Study in Art Education

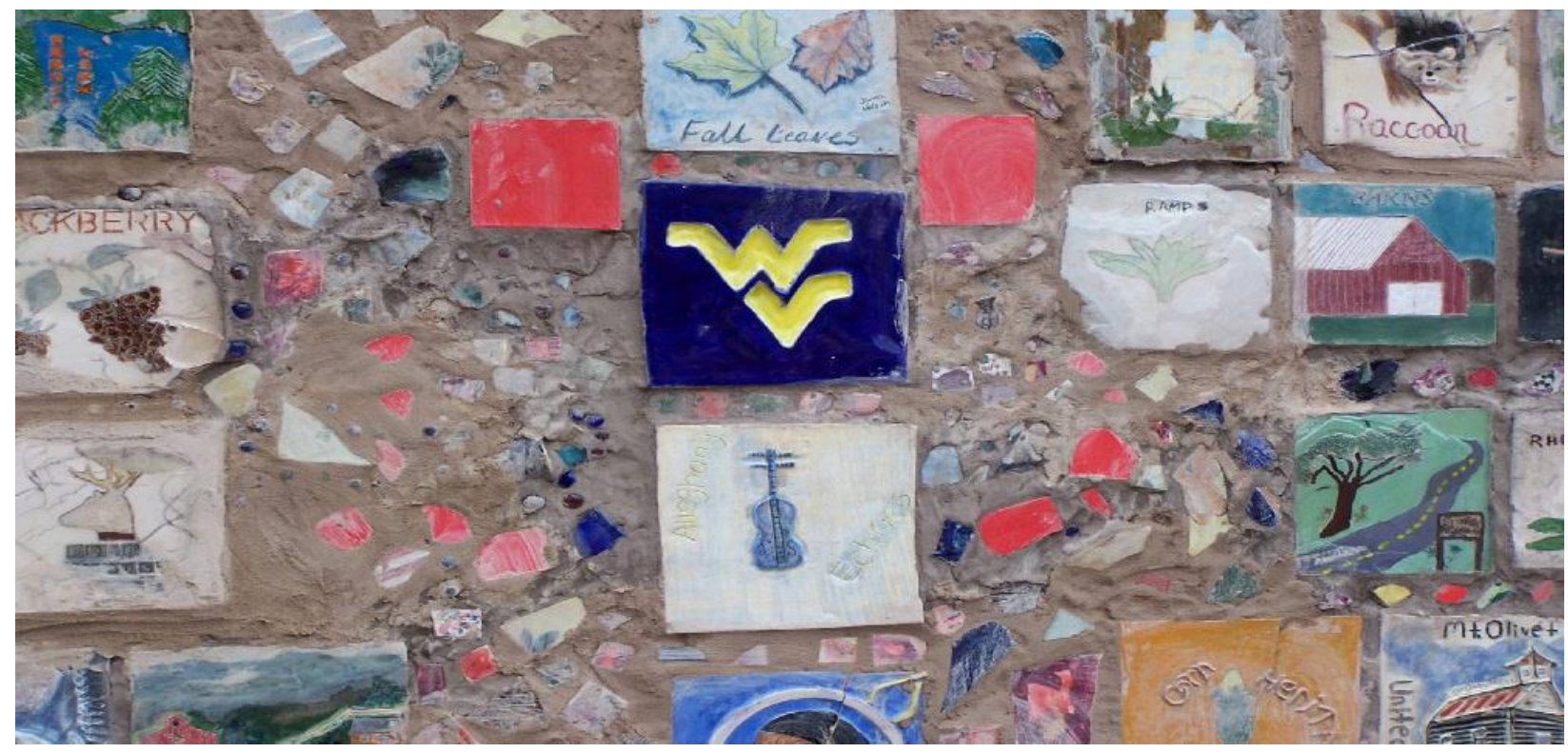

Figure 8- Pocahontas County Installation Mural-A grant funded installation mural done in collaboration with a local elementary school in Pocahontas County, WV. The theme is West Virginia. (See also Appendix D)

In Pocahontas County, WV, an art educator received grant from a local arts council to develop a collaborative arts project with Elementary students. For this project students learned the process and technique in working with clay, making small scale ceramic tiles. Students painted and glazed tiles that were later incorporated into an outdoor installation mural. Tile imagery included subject matter and symbols which represent the state of West Virginia. Tile designs included visuals such as deer/hunting scenes, ramps, maple leaves, the Mountaineer's school logo, and local buildings. This project taught students about the process and technique of working with clay while creating artwork symbolizes their community and state. Place-based projects can be considered community-based or experiential, with lessons that relate directly to the students environments.

1. Can you think of a lesson that you have done with your students that is West Virginiabased such as the example I gave?

2. If no, what about an environmental project or lesson? For example: Talking to students about recycling and using recycled materials to make artworks. 
3. Have you ever taken a class on a fieldtrip to a local community organization, to help students learn more about a specific project?

4. Do you ever take students outside to sketch, on site?

5. Have there been any projects or lessons that you've done with students, where they used gathered materials from outside and/or created artwork with found objects?

6. Do you think there are limitations to West Virginia based lessons, like the project example that I provided?

7. Do you think your students would be more engaged and motivated to do projects coupled with a fieldtrip or community outing?

8. Do you typically integrate new lessons into your curricula each year? What agendas do you consider when planning for an upcoming school year?

9. Have you ever done a collaborative, multidisciplinary project? Can you give me an example of one that you have done?

10. Have you worked with the community/community members on an art lesson or project?

11. What, in your opinion, are the limitations of doing a collaborative project, with other teachers, organizations, or community members?

12. What do you think the limitations are for creating West Virginia-based projects that still meet content standards and goals?

13. Does your school have parents who are actively involved with the school, volunteers to help out in the art room? Would West Virginia based lessons be easier if you had more parental support?

14. Do you think it's reasonable to incorporate one or two West Virginia based projects into your curricula each school year? How do you think your students would respond to these lessons? 
15. Can you tell me a little about the school's policy on fieldtrips? And whether the school ever helps to fund fieldtrips?

16. What do you hope for your students to gain and learn from your art classes in the long term?

17. Do you think the visual arts are in some way a reflection of the artist's surroundings?

18. Would discussing artworks which reflect an artist's cultural and environmental background be something that you're interested in exploring and teaching your students? 


\title{
APPENDIX C
}

\section{SAMPLE COMMUNITY SPECIALIST INTERVIEW CONSENT FORM}

\author{
MARIE DREXLER \\ Applications of Place-Based Education in an Art Curriculum for West Virginia \\ Qualitative Study in Art Education
}

I___ agree to participate in Marie Drexler's Master's of Art paper, in partial fulfillment for her degree through West Virginia University's Art Education program.

I know that my responses will be recorded and used for publication. Responses used within this paper will be recorded, by hand, and used in a manner that my identity will not be revealed. It is ensured that my identity may not be linked through any direct associations. I am also aware that it is my right to back out of this interview process and my participation in this study can be stopped at any time.

Signature:

Date:

\section{COMMUNITY SPECIALIST QUESTIONNAIRE}

How many years have you been working for your community program?

How many community programs have you worked for?

If you answered more than one for the above question, were any of the community programs you worked for outside of the state of West Virginia? (How many were outside of West Virginia?)

Have you taught local student groups/organizations? What age range have you taught/worked with?

Were you born in West Virginia?

Do you have an interest in environmental issues?

Do you have any interest in teaching about art that brings awareness to cultural and/or environmental issues?

Are you a member of any other community or education organizations? If yes, please provide the names of these education organizations. 


\title{
APPENDIX D \\ SAMPLE COMMUNITY SPECIALIST INTERVIEW QUESTIONNAIRE
}

[Before each response a code(s) abbreviation was assigned for the analysis in Chapter 4.]

\author{
MARIE DREXLER \\ Applications of Place-Based Education in an Art Curriculum for West Virginia \\ Qualitative Study in Art Education
}

In Pocahontas County, WV, an art educator received grant from a local arts council to develop a collaborative arts project with Elementary students. For this project students learned the process and technique in working with clay, making small scale ceramic tiles. Students painted and glazed tiles that were later incorporated into an outdoor installation mural. Tile imagery included subject matter and symbols which represent the state of West Virginia. Tile designs included visuals such as deer/hunting scenes, ramps, maple leaves, the Mountaineer's school logo, and local buildings. This project taught students about the process and technique of working with clay while creating artwork symbolizes their community and state. Place-based projects can be considered community-based or experiential, with lessons that relate directly to the students environments.

1. Can you tell me about any projects or classes that you offer through your program that is West Virginia-based like the example I gave?

2. Could you see any of the projects or classes that you offer as part of a public school curriculum? (In other words, do you think a public school could offer the same projects and/or lessons as your program?

3. Are you at all familiar with West Virginia state content standards? Has your program ever followed, or researched, West Virginia's Board of Education content standards and objectives for teaching?

4. What do you want students to take away from their experience and involvement in your program?

5. Have you worked on any collaborative projects/classes with local West Virginia schools? Can you give me an example of a collaboration project that your program has participated in, within the last two years?

6. What do you think are limitations to your program collaborating with local school? 
7. In your opinion, do you think working with local schools is beneficial to the community? If yes, in what way?

8. Do you believe your program contributes to the advancement of West Virginia? If yes, in what way? 


\section{APPENDIX E}

\section{ART EDUCATOR INTERVIEW RESPONSES TRANSCRIBED}

[Before each response a code(s) abbreviation was assigned for the analysis in Chapter 4.]

AE 1: February 7, 2012 @ 4pm

High School Art Teacher; Monongalia County, WV

1. Can you think of a lesson that you have done with your students that is West Virginiabased such as the example I gave?

(EP) My students do a printmaking lesson based on the artwork of artist Blanche Lazzell, born in Monongalia County and from West Virginia. Lazzell was part of the modern art movement and created line cut prints, which were run through the press, and then hand colored with watercolor paints. The teacher that preceded me started doing this lesson with students and I have continued to use it [this lesson] each school year. At the time when we started doing this project, several years ago, West Virginia University was doing a retrospective exhibit of her work and students at that time got to see her work as part of the lesson. However, this was before I started teaching here.

(EP) When I started at the school and began doing this Lazzell printmaking project, some of her family members were attending our school. One of our students, several years back, a family member of hers, brought in a collection of Lazzell's works for our students to see first-hand. For this project, students are able to make their prints based on a theme that they have selected to focus on for the semester, so even though these works are based on a native West Virginia artist the imagery is not necessarily West Virginia themed. These themes are meant to lead up to their Advanced Placement portfolios.

2. If no, what about an environmental project or lesson? For example: Talking to students about recycling and using recycled materials to make artworks.

$(\boldsymbol{E P})(\boldsymbol{E A}) \quad Y$ es, of course we do things like that in our lessons, for example we have used old computers and electronics. I had a student teacher who did a project with the students where they designed and built a city using old, recycled, electronics and computers that the school was getting rid of and which students donated. We have also made junk sculptures with found objects.

3. Have you ever taken a class on a fieldtrip to a local community organization, to help students learn more about a specific project?

(SP) No, I have never been able to take a class on a fieldtrip because of the time involved, the permission, and getting the county's approval. These are things 
that become difficult because you need to give the county at least three weeks for approval and at least one week planning for transportation.

(SL) By the time I could get approval then the project would be complete, trips need about two months of prep time.

4. Do you ever take students outside to sketch, on site?

(FS) I used to take my students outside occasionally, particularly with my smaller classes. I have only ever brought my advanced students out, none of the Art I classes, because they are a smaller group of students.

(SL) However, sometimes you run into a problem when students go out because they get distracted or lack the motivation to work. They sometimes think that going outside is more just to be out of the classroom and relax/socialize rather than work.

5. Have there been any projects or lessons that you've done with students, where they used gathered materials from outside and/or created artwork with found objects?

(SL) (EA) My classes haven't done any specific projects with that but I have had students use found materials that they incorporate into their artwork. Some of my Art I: Intro students who are more driven have asked if they can incorporate found materials into the work.

(BE) If students are going to think creatively then I give them the opportunity to do it.

6. Do you think there are limitations to West Virginia based lessons, like the project example that I provided?

(EC) I don't think there is a limitation, the possibility is out there. I haven't been involved in that with school but have done that as an educator in a summer arts program, that I was involved in a few years ago. If you have the connections and are motivated to do the footwork, there is a want and need to do these projects. These projects just require time, resources, and patrons to help do them.

(SL) In order to do that you would have to work your tail off. Your time as a teacher is limited, and the extra time that something like this would take out of the classroom would be extensive.

7. Do you think your students would be more engaged and motivated to do projects coupled with a fieldtrip or community outing? 
(BE) Yeah, something that translates outside of class might strike a chord with a lot of the students. I think that upper level school students would be motivated, that is depending on the fieldtrip and where you take the students. In terms of the Art I: Intro students, the classes may be interested but there is a wide range of interests in those classes. It is very hard to meet the needs of all these students.

8. Do you typically integrate new lessons into your curricula each year? What agendas do you consider when planning for an upcoming school year?

(SP) Materials and what classes I am actually teaching tend to motivate my planning, also the make-up of the class. I have to think about how many students have modifications and frankly how bored I am with a project.

There are certain projects that I cycle through ever year because the students really enjoy them and because they are good lessons for teaching the basics, like lessons on the color wheel. For this kind of lesson it makes you wonder how many ways can you really teach the same material. For the Art I: Intro level classes there are certain things that I have to cover so it's figuring out different ways to teach these specifics.

9. Have you ever done a collaborative, multidisciplinary project? Can you give me an example of one that you have done?

(EC) A couple times I have tried to do projects with other teachers and what happens is that these other teachers see a collaboration with the art department as a way to push the project into the arts room so they can get an extra free period for planning. I have done a few collaborative projects with our school's history teachers; these were based on colonial times and the arts and crafts of that time period.

(SL) The history teachers wanted the art department to make arts and crafts such as basket weaving, and tapestry weaving but I didn't think these projects really utilized my skills as an art teacher. Ultimately though, for these projects to really work you need a good partner to work with.

These projects can be really helpful to students to show that arts have applications outside the art classroom.

10. Have you worked with the community/community members on an art lesson or project? 
(CO) (SL) We used to do a monthly revolving art exhibit, where we found local businesses that would display the students works. This required a lot of time and work, particularly installing these works.

(EC) (SL) I personally have done community art projects with a summer arts program that I used to be part of. We made huge figure-based sculptures, constructed from sheets of Styrofoam, and were going to install/display these works on the streets of Morgantown for the community to see. This project never was displayed because of funding and lack of planning. Often these projects start off with a great idea but participants don't always have enough foresight to see all the work that a project will entail and thus loose the momentum.

11. What, in your opinion, are the limitations of doing a collaborative project, with other teachers, organizations, or community members?

(SP) $(\boldsymbol{E C}) \quad$ I think first and foremost time, if it involves money where does the funding come from. Also, if all parties are aware of what the project entails and are people willing to do their share of the work.

12. What do you think the limitations are for creating West Virginia-based projects that still meet content standards and goals?

(CSO) No there is enough out there and with the influx of people and influences; there is definitely a means for creating West Virginia-based lessons. There is enough history in West Virginia that there shouldn't be a problem [covering local arts].

(BE) There is a diversity of people moving to the area which helps create opportunities for learning.

There is definitely a way; the only limits are in the teacher's thinking. Depending on the area that you live in West Virginia you might have to watch and tailor your lessons because there is a lack of diversity in the community, but even there you can address issues like coal mining.

13. Does your school have parents who are actively involved with the school, volunteers to help out in the art room? Would West Virginia based lessons be easier if you had more parental support?

(CO) (BE) No parent volunteers specifically have come to the art room. In the past we have had parents who get involved and support the school and other school subjects. It would be great if parents who are business owners and community specialists could give support and could be involved in our arts 
program that would be great. For example, they could display our artwork at their work place so that the community is seeing students work.

14. Do you think it's reasonable to incorporate one or two West Virginia based projects into your curricula each school year? How do you think your students would respond to these lessons?

(CSO) No there is nothing unreasonable about that and as far as the CSOs there's no limitations because they are open enough.

(BE) It does help open students eyes if lessons go beyond the classroom. I think probably that overall most students would be fairly engaged, of course there will always be some who don't like it however you can't always please everyone.

15. Can you tell me a little about the school's policy on fieldtrips? And whether the school ever helps to fund fieldtrips?

(SP) The school county policy for fieldtrip approval must be two weeks in advance and the board (who approves trips) meets every other week. If it's an in county trip the bus should be free, but I'm not sure if that rule applies to the High school as well. If the county doesn't provide free transportation for your trip then you have to raise money and plan transportation yourself.

16. What do you hope for your students to gain and learn from your art classes in the long term?

(BE) I want students to see that there is a bigger connection in what they learn in the studio process. That they don't need to just be an artist, they can take these skills and apply them elsewhere. I want them to learn critical thinking skill and to have a better appreciation for what they see, understanding aesthetics in a more broad appreciation.

17. Do you think the visual arts are in some way a reflection of the artist's surroundings?

(BE) Definitely, I think that's the number one influence, particularly studying what materials artists can get and what they use, what is going on politically where they live. These all play a major role in what the artist is making.

18. Would discussing artworks which reflect an artist's cultural and environmental background be something that you're interested in exploring and teaching your students?

(CSO) I do incorporate that into every lesson that I teach. For example teaching about the color wheel I did a lesson based on Andy Warhol and pop art, 
the students incorporated a specific color scheme in the two-dimensional artworks. We talked about where Warhol is from and what the pop art movement was about.

(CSO) $(\boldsymbol{B E}) \quad$ I offer an art appreciation class which incorporates studies of the humanities and looks at the different art styles, time periods, and locations/cultures of artists and what happened during that time. They also make artwork, creating project-based on the style of art that the students are learning about. I provide the materials and some structure to the projects but students are free to make their interpretations from that time period and style. This is a good class but is only offered if enough students sign up for it.

AE 2: February 16, 2012 @ 12pm

Elementary School Art Teacher; Monongalia County

1. Can you think of a lesson that you have done with your students that is West Virginiabased such as the example I gave?

(CO) Not really, well the empty bowls project could be considered a service learning project, but it's not teaching students about West Virginia.

(EP) When I was teaching at one of my other schools, still in West Virginia, we had a visiting artist (who painted landscapes of West Virginia) come in and did a demonstration for the school in the gym. Then the students painted local landscapes using watercolor paints.

2. If no, what about an environmental project or lesson? For example: Talking to students about recycling and using recycled materials to make artworks.

Yes, I have done a lot of recycling and environmental projects. Our classroom uses a lot of recycled materials to make art. Every day, students bring me cardboard tubes, yogurt containers, bottle caps, and cardboard that could be used for making art.

(EP) I have the fifth graders currently working on a collaborative project making architectural sculptures. The students work as a team to make buildings that will be joined together to make one big community display. There are about three or four kids working on one building and they use all the different recycled materials that have been brought in by students throughout the year, including egg cartons and cardboard tubes. The city display will be on exhibit in the school library so that other classes, teachers, and parents who visit can see the collaborative work. 
(EP) Also, I have some of my younger grades making Chinese News Years Dragons using the tops of egg cartons, recycled materials that we collect in the classroom.

3. Have you ever taken a class on a fieldtrip to a local community organization, to help students learn more about a specific project?

(SP) (SL) When I taught in a different state my school then was located near local Art Museums/programs that we took students to. In an elementary public school, here, it is logistically almost impossible to take students on an art fieldtrip. It means dealing with buses and it's up to the classroom teachers that decide where that grade will go. There is only one fieldtrip scheduled for the year.

We have has students work with the community before on projects, for example I had fourth and fifth graders paint a metal snow blade. Those blades that are fixed on the front of snow plows, owned by the city of Morgantown, and used to move snow from the streets. Students used outdoor paints to decorate this blade which was later attached to a plow and used locally in the community through the winter.

4. Do you ever take students outside to sketch, on site?

(FS) We have a courtyard that we sometimes work in which is attached to the classroom, it's a nice safe place to take the kids out into. They have not really gone out to draw what they see though.

(SL) There is a bit of a safety issue with taking the students outside because there is no fence on the playground right now, and it's a pretty busy road that the school is on. I know that until the fence is back up recess is not allowed on the playground so I wouldn't want to take students out there for art.

(EC) I have participated in the pinwheels for peace project and the students went outside to place their pinwheels in the front yard of the school.

5. Have there been any projects or lessons that you've done with students, where they used gathered materials from outside and/or created artwork with found objects?

(EA) (EP) Yes I have had the students use natural materials, like collecting leaves to make crayon resist rubbings. I taught a lesson where students made Native American gods eyes using yarn and collected sticks from outside.

(SL) For these projects I collected the materials on my own time, it's a safety issue to have young kids outside wandering and collecting materials. Also, there 
are no trees on our school ground so there aren't a lot of resources to gather for creating art.

6. Do you think there are limitations to West Virginia based lessons, like the project example that I provided?

(SP) Yes, funding is huge and if you can get a grant then that can take care of that issue. Also the scheduling in public schools is such that you only see kids once a week. This is all 'do-able' but it just takes more planning, but that's everywhere not just here in West Virginia. It's not impossible but it is just hard. One solution to that could be seeing all the grades in one day, in this way an art teacher wouldn't have to constantly be switching from one project to the next. But this depends on the school and county to decide if the specials classes can have all the same grades on the same day, but it would allow you opportunity to do more. Each county has different guidelines, one might be that teachers get ten minutes between classes but the only guideline I think our county has is that we see every class once a week for 40 minutes.

7. Do you think your students would be more engaged and motivated to do projects coupled with a fieldtrip or community outing?

(FS) Absolutely, any time they go on a fieldtrip the students get really excited to be outside of the school and doing hands-on activities.

(BE) Experiencing things out of school is a good break from worksheets, and they do a lot of worksheets.

8. Do you typically integrate new lessons into your curricula each year? What agendas do you consider when planning for an upcoming school year?

(SP) Personally, I don't like to do the same thing each year because it gets pretty monotonous. Some of the lessons that I find to be really successful I rotate and reuse. I do all my ordering over the summer; get all my supplies so that I can use all my funding efficiently. I go through books and magazines to get some ideas. In terms of our budget, here in Monongalia County, it's more than most rural counties in West Virginia so we are very fortunate.

9. Have you ever done a collaborative, multidisciplinary project? Can you give me an example of one that you have done?

(SP) (SL) Yes, it is tough to do particularly having the schedule the way it is, it's a lot easier to plan with grades when we have all the students in one grade on the same day. In Virginia we had a spotlight in education and parents would come in and watch/come see students art or perform a music project. It makes a difference how much the county emphasizes the arts, and the support that you get from administration. 
$(\boldsymbol{E P})(\boldsymbol{E C}) \quad I$ did one collaborative project with $1^{\text {st }}$ graders and their homeroom teacher. They were learning about the three parts of insects so we had students make and design their own bugs using clay. The kids then got to paint their little bug sculptures, a good interactive arts activity to go with the lesson. Also, I have done tessellations with different classes, the $4^{\text {th }}$ and $5^{\text {th }}$ graders, and many symmetry projects that go along with math lessons, particularly on learning fractions.

10. Have you worked with the community/community members on an art lesson or project?

It has been about 4 or five years but I did work on the Isaiah Zagar inspired community tile mural project. The community draws out the design for the mural and then breaks up ceramic pieces and mirrors and grouts them into the work. It was a lot of work but really very rewarding. This is something that I did as an educator during my summer and some of the student's ceramic works were used in that mural.

(SL) This particular community mural is displayed at Dorsey's Knob, I have wanted to do a mural with the kids but it's hard with kids who are really young.

11. What, in your opinion, are the limitations of doing a collaborative project, with other teachers, organizations, or community members?

(CO) (EP) I have been working on an empty bowls project, students get to decorate a ceramic bowl that gets glazed and then sold to the community to help raise money for charity, the homeless. This project was a huge deal and took a lot of time and planning. The money was the most challenging part, not impossible but it just takes time finding the funding and support.

12. What do you think the limitations are for creating West Virginia-based projects that still meet content standards and goals?

(CSO) Probably just the finances, the CSOs are open enough and there are so many different lessons you can use for them. CSOs aren't too specific in the sense that they are limiting.

13. Does your school have parents who are actively involved with the school, volunteers to help out in the art room? Would West Virginia based lessons be easier if you had more parental support?

(CO) Yes, we have a list of parent volunteers and there are people who will come in and help but a lot of parents work. Parents work and so their schedule is limited and that makes it difficult to find volunteers for more than an hour a week. 
We are very lucky that we have parents who have the time to come in. There are lots of counties in West Virginia that probably have parents who work all the time.

14. Do you think it's reasonable to incorporate one or two West Virginia based projects into your curricula each school year? How do you think your students would respond to these lessons?

(CSO) I haven't done any West Virginia-based lessons that I can think of but a few years ago my fourth graders did a program for West Virginia Sings. This is a performance that is put on for parents, but my fourth grade students made a backdrop for the show. The backdrop included a black bear, a mountaineer, rhododendrons, and a cardinal. The fourth grade social studies classes do this every year. Mostly it's the CSOs for fourth grade and kindergarten which focus on West Virginia history.

15. Can you tell me a little about the school's policy on fieldtrips? And whether the school ever helps to fund fieldtrips?

(SP)(FS) The policy on fieldtrips has gotten stricter, and I don't think that I would even be able to do a fieldtrip with students. I would have to work in collaboration with the grade level homeroom teachers. They plan one trip for each grade level and it's worked out and planned months in advance. The whole team of teachers, for the grade level, would have to be on board.

(FS) (SL) Fieldtrips can be a lot because teachers barely have time to cover what they need to in one day so it's tough to get around that lesson time.

16. What do you hope for your students to gain and learn from your art classes in the long term?

(BE) I always feel like in elementary school it's about building kids self confidence. And I think it's important to get students to do higher level thinking, experiential, hands-on, creative problem solving where they use their imagination.

Art teachers have an important job helping kids to be creative.

17. Do you think the visual arts are in some way a reflection of the artist's surroundings?

(EA) My favorite thing to do is pottery and I'm not sure if that's really a reflection of my surroundings. I think it's really more dependent on the artist.

18. Would discussing artworks which reflect an artist's cultural and environmental background be something that you're interested in exploring and teaching your students? 
(EP) (BE) Yes, I try to do this a lot and also our school has a multicultural plan. I did a multicultural lesson recently, teaching students about the Pacific Northwestern Indians and they made totem poles out of cardboards tubes. We talked about the Indians culture, I read them a story that showed pictures of art inspired by their culture and told a story about their history. After the story we talked as a class about the artwork of these Indians.

Students really love to discuss artwork and what they see.

AE 3: February 27, 2012 @ 4pm

Middle School Art Teacher; Monongalia County, WV

1. Can you think of a lesson that you have done with your students that is West Virginiabased such as the example I gave?

(EP) Actually I've done several; one example would be CD mosaics that I have students make using painted and broken CDs. We have begun to take down the ceiling tiles in our school's hallway to decorate then with the students' mosaic designs. The theme has been myths, legends, West Virginia landscapes, and West Virginia tales. I had students make tile designs of the "moth man" and the New River Gorge Bridge, I also had a students do Canaan Valley. For this project ceiling tiles project students usually work collaboratively in small groups.

2. If no, what about an environmental project or lesson? For example: Talking to students about recycling and using recycled materials to make artworks.

(BE) Yes, I always tell my students that there is never any trash in the art room; there are always opportunities to use new and different materials to work with.

$(\boldsymbol{E P})(\boldsymbol{B E}) \quad$ My CD tile mosaics lesson plan and idea was published in the School Art Magazine, in this lesson students recycle old CDs and we talk a lot about recycling. Also, in general our room just uses lots of recycled materials like cardboard and newspapers. I always ask the school administration and other teachers to bring me supplies, like cardboard boxes. I am always interested in using new materials in the art room.

(BE) We also have a paper scrap box, where students can re-use paper scraps or flip over drawings to use the back of a paper.

3. Have you ever taken a class on a fieldtrip to a local community organization, to help students learn more about a specific project?

(FS) (EP) I haven't taken my students from this school on a fieldtrip but I have done many fieldtrips with students over the years. I have taken students at 
my old school, to the Carnegie Art Museum in Pittsburgh and we have been to West Virginia University college portfolio days, to name a few. For this school, I did have my students visit Dorsey's Knob as a homework assignment. I required that they go in groups and to see the community tile mural project [that I was part of], and then take pictures in front of the mural as proof that they were there. This was to help inspire them for their CD mosaic designs.

4. Do you ever take students outside to sketch, on site?

(EP) Absolutely, I have taken kids to sketch outside at Coopers Rock. I also had my student go to local funeral homes in Preston County and required that they have a sketchbook with them to sketch the gargoyles on the buildings; these sketches were then used for a later project.

(EP) Another time I took my students outside to draw trees so they could observe trees from life and then draw what they see.

5. Have there been any projects or lessons that you've done with students, where they used gathered materials from outside and/or created artwork with found objects?

(EA) My students use natural materials in their work sometimes, for example students collected rocks to help balance out their bobble head sculptures. One project that I did was Mother Nature masks and students used twigs, grass, moss, and so forth. Also, I have done painted rocks, students paint little landscapes scenes on their rocks.

6. Do you think there are limitations to West Virginia based lessons, like the project example that I provided?

$(\boldsymbol{E P})(\boldsymbol{C O}) \quad$ I did a community project together with a community specialist last spring, where students made glass mosaics of leaf designs. The students set and glued pre-cut pieces of glass which were later grouted to be used in a community display. It's a little difficult in the middle schools to organize out of school projects because students can't drive yet and afterschool organizations can be tricky.

(SL) The limitations are getting funding and organizing these projects, the spring glass mosaic project was nice because the community specialist brought the project to my classroom. I welcome artists/projects that can be brought here and presented in class.

7. Do you think your students would be more engaged and motivated to do projects coupled with a fieldtrip or community outing? 
(BE) I think it's always a plus, students are motivated anyway but I have noticed that after we go on fieldtrips and see exhibits they get more engaged and it really positively affects their artwork. They are typically enthusiastic about art history and seem to work a little harder.

8. Do you typically integrate new lessons into your curricula each year? What agendas do you consider when planning for an upcoming school year?

(BE) Yes, I get bored with the same projects over and over. Sometimes the students request certain projects though. It's important for an art teacher to stay current, to see exhibits because it motivates and keeps the teacher renewed. My teaching style is always evolving, I like exploring different materials and trying new materials, putting twists on projects, and integrating literature into activities.

9. Have you ever done a collaborative, multidisciplinary project? Can you give me an example of one that you have done?

(EC) Yes, I have done collaborative projects with the theatre department, I taught about the history of mask making in the theatre and students made masks to use for a performance. For another theatre/ music collaboration, while their students performed my kids made improvisational drawings.

(BE) I should note too that it's important to integrate West Virginia culture as well as teaching multicultural lessons so students become aware of and begin to appreciate different cultures as including the local culture here in Morgantown.

10. Have you worked with the community/community members on an art lesson or project?

(EP) (CO) Again, I worked on the community glass mosaics this past spring and for that lesson a community specialist came into the classroom, but I have also had lots of local artists come in and present their work.

For example, my students have had the opportunity to meet Adam Cross a local painter and glass artist Ron Hinkle, and to talk with them about their artworks. I really think the great thing about the glass tile mosaic project was that it brought community specialists into my classroom and allowed them to take over to teach their lesson within the school.

11. What, in your opinion, are the limitations of doing a collaborative project, with other teachers, organizations, or community members?

(SL) (SP) In all honesty, the collaborative projects are much easier to plan working with the high school grade levels just because students have a higher skill level and are able to work on bigger projects. The limitations are a prime 
factor, it seemed like there was a little more time to make collaborations at the high school level as opposed to middle school. The specials classes don't have planning at the same time as the other teachers, and during our PLC time we have education training. It seemed more natural to do between classes because there used to be more time in at the high school level.

12. What do you think the limitations are for creating West Virginia-based projects that still meet content standards and goals?

(BE) I don't think there are limitations, there is a lot to draw from in West Virginia and I love to teach students about the folktales and the beautiful landscapes.

(BE) There's a lot of cool things to draw from in West Virginia, it may be easier to do fieldtrips and collaborations at the high school level but inspirationally there are no limits for West Virginia-based projects. It is especially helpful with the use of the internet because students can look up and find out more information about West Virginia.

13. Does your school have parents who are actively involved with the school, volunteers to help out in the art room? Would West Virginia based lessons be easier if you had more parental support?

(CO) I have had parents come in and help out some, but also parents who are artists have come to present their work. I don't know if I need them in the classroom per say, but our parents here are always very supportive and involved in other ways. They help out by sending in supplies and materials and for example taking students to see the Dorsey's Knob mural after school. We have great parents here who provide a lot of help and support to our school.

14. Do you think it's reasonable to incorporate one or two West Virginia based projects into your curricula each school year? How do you think your students would respond to these lessons?

(BE) $(\boldsymbol{E P}) \quad I$ definitely think it's reasonable and it's good to get students involved, even just having them look at local scenery. It's a natural thing for my class because I have always talked about West Virginia history and our local community. After the Sago Mine Disaster, I had students do a tile project on the 12 miners who were killed and it also included several miners looking out over the landscape. The students were really engaged with the project, they came up with the design and felt very strongly about the message, and I think it was almost therapeutic for them. This tile project is now part of the ceiling tile display in the school hallway. 
15. Can you tell me a little about the school's policy on fieldtrips? And whether the school ever helps to fund fieldtrips?

(SP) We have funds that you can request or you can also ask students to bring in money to help out. I haven't done that much at this school; the school kind of wants the fieldtrips to be done around the same time frame. The policy isn't against fieldtrips they are just harder to squeeze in. I do offer an afterschool studio arts program every Wednesday which is an opportunity for students to do more studio work beyond their art class.

16. What do you hope for your students to gain and learn from your art classes in the long term?

(BE) (CSO) One of the biggest things, regardless of fieldtrips is to convey to students that it's important to have an appreciation for the arts. I want students to know that the arts can always be part of their life in some form or another, that they can think creatively and out of the box. The skills they learn are hobbies or can help them to see the world in a broader way. I think that students culturally experience a lot just from learning about art history. Art is an accepting field, a non-judgmental field.

17. Do you think the visual arts are in some way a reflection of the artist's surroundings?

(BE) I think that an artist's surrounding can be an inspiration for creating art but it's not one specific thing. I think art and inspiration can go beyond that as well, it isn't in any one box.

18. Would discussing artworks which reflect an artist's cultural and environmental background be something that you're interested in exploring and teaching your students?

(BE) (CSO) I think I have done a lot of that and I'm always open to learning more about different artists. Sometimes I think my students teach me, they really bring a lot of themselves into their artwork. I want my students to express themselves and feel like they can compete and improve with their work. The art room helps them grow beyond the classroom to develop their creativity skills and appreciation. 


\section{APPENDIX F \\ COMMUNITY SPECIALIST INTERVIEW RESPONSES TRANSCRIBED}

CS 1: February 27'2012 @ 3pm (Partial, teacher has scheduled the completion.) Friends of Decker's Creek Organization

1. Can you tell me about any projects or classes that you offer through your program that is West Virginia-based like the example I gave?

(EP) We have done several projects of this nature with our Youth Advisory Board (YAB) and community partners. Working with BOPARC's Arts in the Park program we designed, created, and installed glass mosaics in the Friends of Deckers Creek Outdoor Learning Park. The mosaics are stream affiliated wildlife and include a crayfish, salamander, bass, and dragonfly. YAB members researched information on these creatures including their life-history, habitat preferences, and where they can be found in the Deckers Creek watershed. These reports were turned into posters mounted on the backs of the mosaic pieces. YAB members also helped with the installation of native plant gardens, artistic rock borders, signage, pavilion, and benches in the Outdoor Learning Park.

(EP) We have also painted three stream-inspired murals in the community. One is titled "We All Live Downstream" and the other is called "All Hands-on Deckers". Both of these murals are featured along the Deckers Creek rail-trail in downtown Morgantown. YAB members helped to design and paint both of these murals learning about the importance of watersheds, aquatic wildlife, and community beautification. The other mural is featured at the Morgantown Learning Academy.

2. Could you see any of the projects or classes that you offer through your program as part of a public school curriculum? (In other words, do you think a public school could do the same projects and/or lessons as your program?

(EA) Yes, for example I can see art and science teachers teaming up to do riverbased projects where students learn about watersheds, how to sample for pollutants, and do stream-related art projects based on their findings.

3. Are you at all familiar with West Virginia state content standards? Has your program ever followed, or researched, West Virginia's Board of Education content standards and objectives for the teaching?

(CSO) (EP) Yes I am familiar. We do not follow the CSOs for YAB projects, but we do try to work them into our education projects with local schools. For instance, YAB will be going into High School classrooms this spring through our Youth Watershed Bill of Rights project to teach students about watersheds, stream pollutants, how to use water monitoring probes, etc. The students will then get 
equipment to sample local streams for 1-2 weeks and bring their data back to map and analyze.

4. What do you want students to take away from their experience and involvement in your program?

(CO) (EA) We want youth to become more familiar and engaged with their local environment in general and with streams in particular, to become better environmental stewards, civically engaged, and to feel important within their community. We also seek to improve their science inquiry, leadership, public speaking, and team working skills.

5. Have you worked on any collaborative projects/classes with local West Virginia schools? Can you give me an example of a collaboration project that your program has participated in, within the last two years?

(EP) (CO) The BOPARC Arts in the Park collaboration is a good example. And we are going to be working with Morgantown High School, University High School, and Preston High School this spring on the Youth Watershed Bill of Rights project described above.

6. What do you think are limitations to your program collaborating with local school?

(SL) Scheduling and finding teachers willing to collaborate with.

7. In your opinion, do you think working with local schools is beneficial to the community? If yes, in what way?

(BE) (CO) Absolutely! It's a great way to get students involved with their local non-profit and community. It gives them a better sense of place and community.

8. Do you believe your program contributes to the advancement of West Virginia? If yes, in what way?

(CO) Yes. We are educating and empowering youth who will be the future leaders of watersheds.

CS 2: March 7, 2012 @ 9:30am

Morgantown Learning Academy 
1. Can you tell me about any projects or classes that you offer through your program that is West Virginia-based like the example I gave?

We don't have any summer programs or workshops that are specifically West Virginia-based; however our summer programs do have weekly themes and include activities such as creating ceramic tile mosaics and cooking different cultural foods as part of our international workshop.

$(\boldsymbol{E P})(\boldsymbol{C O}) \quad$ We did a summer project last year with West Run Water Association and Friends of Decker's Creek. For this project students learned about West Virginia stream beds and then the students got to help design and paint a mural on one of Morgantown Learning Academy's school fences. The mural was themed West Virginia streams; our program here really does a lot with community service.

2. Could you see any of the projects or classes that you offer as part of a public school curriculum? (In other words, do you think a public school could offer the same projects and/or lessons as your program?

(BE) (CSO) I think the lessons associated with these programs and workshops could easily be incorporated into school curricula. For example students could learn a full lesson on the process of making tile mosaics, or on researching and making different cultural foods for a social studies international lesson. Mainly our summer workshops and programs are fun and educational and more activity based. These programs are meant to give the students something different from their normal routine school experiences.

3. Are you at all familiar with West Virginia state content standards? Has your program ever followed, or researched, West Virginia's Board of Education content standards and objectives for teaching?

(CSO) (BE) We don't look at CSOs as much for our summer programs, but our projects definitely have an educational focus and do follow West Virginia content standards. There is a variety of topics that we cover in our summer programs and workshops but all of these are very experiential and hands-on. Because our activities are more experiential, students seem to learn more and really get interested in learning; we really want to make education fun. I have noticed that our students are exceeding the CSOs; they are engaged with learning and doing great.

Also, it should be mentioned that we have a lot arts and music integrations in our summer programs.

4. What do you want students to take away from their experience and involvement in your program? 
(PC) It's a summer program so we don't want to have quite as much structure as the school year, we try to provide experiences that are fun and engage children in learning. Also important is for us to incorporate activities that help maintain what is learned in the school year, because a lot gets lost in the summer months.

Our program wants to give students fun experiences to build a natural love for education outside of school.

5. Have you worked on any collaborative projects/classes with local West Virginia schools? Can you give me an example of a collaboration project that your program has participated in, within the last two years?

(CO) $(\boldsymbol{B E}) \quad$ Our school and summer programs are very hands-on, we have a lot of community speakers come into the school such as West Run Watershed Association, WOW pottery factory, Stonewall Jackson Resort, Valley Ridge Farms, and the West Virginia Raptor Rehabilitation Center.

$(\boldsymbol{C O})(\boldsymbol{B E}) \quad$ One collaborative project that we did here was with the Stonewall Jackson Resort; specialists came to our program and did some art based projects with the students. These projects included activities such as weaving, rope making and marbling paper. They have also brought furs, animal teeth, and fossils for the students to touch and see firsthand. Also, the West Run workshop mural project was done in collaboration with Friends of Decker's Creek.

(BE) It's really hard in the summer to plan and do fieldtrips because of transportation so we try to bring those experiences here. We have an outdoor classroom which is a great space for students to be able to be lean and experience the outdoors.

6. What do you think are limitations to your program collaborating with local school?

(EC) Our program is already affiliated with our school, we do a lot of student collaborations and peer-teaching in our school program. The school really emphasizes students working together.

(PC) We get students from other schools in our summer program. With our summer program, for instructor to student ratio and the sign-up is by week, so I would say that it's a great deal for parents. We need to have our schedules set by May $5^{\text {th }}$, so then parents are contractually bound to whatever they sign their students up for but prior to that our scheduling is pretty open. 
7. In your opinion, do you think working with local schools is beneficial to the community? If yes, in what way?

(BE) (CO) We have created a little family here at our school. We have a lot of community outreach projects that are part of our school curricula because we want the students to understand more about civic duties and how to we can take care of each other.

(BE) We have campus food drives, clean-up days, and a small garden that our summer program gets involved in. We want to get children to be a part of their own space.

8. Do you believe your program contributes to the advancement of West Virginia? If yes, in what way?

(BE) (CO) Absolutely, I think that any time children are involved in their community that has positive effects on the states. It allows for children to experience and be exposed to education that relates to their own interests. Getting involved in the community gets students thinking that's outside the box, which is really important for making new discoveries.

CS 3: March 8, 2012@ 3pm

WVU Community Arts Program

1. Can you tell me about any projects or classes that you offer through your program that is West Virginia-based like the example I gave?

(EP) (CO) We have done quite a few community projects; for the past ten years Morgantown's summer program, Arts in the Parks, has focused the community on children's painted murals. Each summer we have done a mural with a different theme, for example one summer we had West Virginia Literature and another year it was West Virginia Native Animals and Plants. For the West Virginia Literature mural, three West Virginia writers came to our program space and talked to students. Then students did their own creative writing and their writings became the inspiration and design for a three panel mural that is on the exterior of the Old Chamber of Commerce building in downtown Morgantown.

2. Could you see any of the projects or classes that you offer as part of a public school curriculum? (In other words, do you think a public school could offer the same projects and/or lessons as your program?

$(\boldsymbol{E C})(\boldsymbol{E P})(\boldsymbol{C O})(\boldsymbol{P C}) \quad I$ have been in close contact with the art teachers in this community; I talk with them and attend their Art Education meetings. Some of the Monongalia county public schools here have been involved in our big current mixed media tile project entitled "A Celebration of Diversity." For this project I go into the schools to help facilitate the project, bringing along supplies and helping to instruct the first few classes. In this way, I am bringing the project to them, and the way it works is that I start off working with the art teacher, co- 
teaching, and then they will take over as the students continue to work on the project.

3. Are you at all familiar with West Virginia state content standards? Has your program ever followed, or researched, West Virginia's Board of Education content standards and objectives for teaching?

(CSO) (BE) I taught as a classroom teacher for twenty years so I am very familiar with the CSOs. I wouldn't say that projects like the 'Celebration of Diversity' set out with the CSOs in mind but it's almost impossible not to meet them.

4. What do you want students to take away from their experience and involvement in your program?

(BE) I want students to be part of something that's bigger than them, and involved in their community. These projects are about building students' sense of place and pride in their community. Art can enrich a community and help make it healthy.

5. Have you worked on any collaborative projects/classes with local West Virginia schools? Can you give me an example of a collaboration project that your program has participated in, within the last two years?

$(\boldsymbol{E P})(\boldsymbol{C O})(\boldsymbol{B E}) \quad$ We are currently working on two big collaborative projects, one is a ceramic and glass mural that will be displayed down by the riverfront in Morgantown. It will be in a little green space near the rail trail that our program owns. We are working with the community, different schools and civic organizations, to make individual leaves that will be collectively displayed to form one large tree. This project is called "A Celebration of Diversity" and the idea of this project is basically "peace" through art because the tree takes on the shape of a globe, it's based on Laurie Marshall's singing tree project.

$(\boldsymbol{E P})(\boldsymbol{E C})(\boldsymbol{B E}) \quad$ Our program is also working with an elementary school in Fiji; it is basically the same concept as the "Celebration for Diversity." Students in Morgantown are drawing prism colored leaves. These leaves will be combined with the drawings that students from Fiji create to make one big collaborative mural that will be displayed within the Fiji school building. The drawings are glued onto a big backing and then sealed with acyclic glue. The leaves that students are creating either depict imagery of what is important to students or what they wish for the world. There are two ways to approach the project; one way is that at the very root all children are the same and the second is to bring together our dreams and ideas about the world as one. 
6. What do you think are limitations to your program collaborating with local school?

(SL) All the normal problems, mostly just space and budget but theoretically there shouldn't really be any other limitations. In fact I think more collaboration should be done with the schools and community.

7. In your opinion, do you think working with local schools is beneficial to the community? If yes, in what way?

(SL) Absolutely, it seems there is more of an emphasis and exposure to sports particularly at the high school level, but not so much for the arts in Morgantown. I think sometimes art gets lost in the shuffle, but getting students engaged and involved in where they live is really important to the health of the community. If you look at a healthy and thriving community, they usually have public art.

8. Do you believe your program contributes to the advancement of West Virginia? If yes, in what way?

(CO) Absolutely, I think it benefits the kids in so many ways, it opens their eyes to new connections and possibilities, and they get a larger connection with the world.

(BE) I think that of all the subjects in school, art is one of the primary ones (not the only) that helps to develop students creative problem-solving and a good art educator teaches that to students. It is important for an art educator to realize that not all kids are artists but art can be a way of sparking student's interests and getting them to think creatively. 


\section{APPENDIX G}

\section{A LIST OF WEST VIRGINIA COMMUNITY PROGRAMS AND RESOURCES}

\section{Place-Based Project (Dunmore, WV)}

The Pocahontas Arts space is being utilized as an art gallery and class room place. We are featuring the art work of area artists in various media including oil, acrylic, watercolor, pen \& ink, jewelry and more. We are offering art classes in these media as well. Please see the art classes' page for a complete class schedule.

If you would like to contact them regarding grant applications, scholarships or our mentorship program, please contact our president Arthur Kreft at arthur@pocahontasarts.org or by phone at 304-799-2438 or by mail at PCAC PO Box 251, Marlinton WV 24954."

http://pocahontasarts.org/

\section{Environmental Education and Field Experience (Wheeling, WV)}

“The West Virginia Environmental Education Association conserves West Virginia's natural and cultural heritage by fostering an environmentally literate and responsible public. This is accomplished through connecting, training and supporting a community of stewards through education in order to promote an environmentally aware and responsible citizenry." http://wveea.org/content/view/13/50/

\section{Art Education (PrK to Older Teens): Studio Centered Classes (Elkins, WV)}

"We provide a home for local and visiting artists across a wide variety of media. From exhibits to performances to art education, the Center is supported by the community it serves. Take a look at 2011-2012 concerts and class schedules, download their newsletter. If interested in supporting the Art Center, become a member-it's an investment in the community as well as yourself." http://randolpharts.org/classes.html

\section{Museum Education; Community Opportunities (Huntington, WV)}

Education Department for the Huntington Museum of Art which includes camps and classes; collection includes West Virginia Artists.

http://www.hmoa.org/

\section{Visual Arts Education Opportunities (Wheeling, WV)}

The Ogelbay Institute, Stifel Fine Arts Program, in Wheeling, West Virginia offers visuals classes/workshops for kids of all ages, including Pre-K students. http://www.oionline.com/education/index.htm

Service Projects and Place-Based Learning (Morgantown, WV) 
"The FODC Youth Advisory Board (YAB) is a group of dedicated youth ages 18 and younger interested in clean water and helping the community. Their mission is to increase youth participation in helping clean up the Deckers Creek watershed for conservation, preservation, and recreation through youth-led projects and research."

http://www.deckerscreek.org/index.php?option=com_content\&view=category\&layout=blog\&id $=52 \&$ Itemid $=77$

\section{Museum Education and Classes (Parkersburg, WV)}

"Founded in 1938 by members of the Parkersburg WV Woman's Club, the Art Center is the oldest arts organization in WV in continuous operation! Now in its fifth home, the Art Center is located on a busy corner right downtown. The facility houses six separate gallery areas (including one just for kids!) that can be used individually or in tandem, and those galleries hold an average of 16 exhibits each year. Shows range from the works of internationally known artists though art by area schoolchildren, and there is ALWAYS something interesting to see." http://parkersburgartcenter.org/

\section{Adopt a School Program and Workshops (Berkley Springs, WV)}

"Established at a public meeting in May 1977, the non-profit Morgan Arts Council has produced more than a thousand programs with nearly 2400 artists, benefitting thousands of visitors and residents including students in all county schools. Presentations have included concerts, arts workshops, and pageants, entertainment at the Apple Butter Festival, craft studio tours, professional art shows, storytellers, theater and video festivals."

http://macicehouse.org/artsed.html

\section{Community Arts Program (Morgantown, WV)}

"The Morgantown Board of Park and Recreation Commissioners (BOPARC) are dedicated to promoting community-based, indoor and outdoor recreation for people of all ages and abilities, in the greater Morgantown area. To this end, BOPARC is committed to providing and continually upgrading parks, facilities, and programs that promote active and healthy life skills, as well as a strong sense of neighborhood and community. In addition, BOPARC is committed to responsible stewardship of our community parklands, greenways, trails, and historic sites, because of the value these areas add to the overall quality of life for Morgantown area residents and visitors."

http://www.boparc.org/index.php?option=com_content\&task=category\&sectionid=4\&id=37\&Ite $\underline{\operatorname{mid}=3}$

Other helpful resources include:

1. http://www.promiseofplace.org/,

2. http://www.ycfwv.org/

3. http://www.wvculture.org/arts/artists.html and

4. David Sobel's Place-Based Education: Connecting Classrooms \& Communities 


\section{APPENDIX H \\ INTRODUCTORY PLACE-BASED LESSONS FOR WEST VIRGINIA ART EDUCATORS}

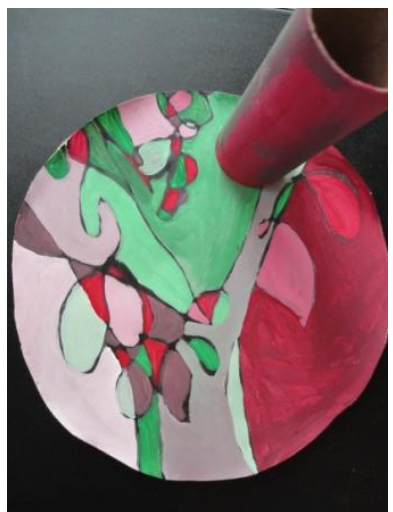

Hindu and Buddhist Sacred Art Forms (Mandala: means 'circle')

Title: View-Finder Mandalas; My Natural Environment is a Sacred Place

Teacher: Marie Drexler

Grade Level: $3^{\text {rd }}$ Grade

\section{Instructional Objectives: West Virginia CSO's}

\section{Students will:}

- Apply problem-solving skills in creating two-dimensional works of art

- Identify selected elements and principles of design as they relate to art and the environment

- Demonstrate an understanding of how history, culture, and the arts influence each other

- Identify multiple purposes for creating works of art

- Analyze by comparing and contrasting connections between disciplines

\begin{tabular}{|l|l|}
\hline VA.O.3.1.1 & $\begin{array}{l}\text { Compare how different techniques and processes in various drawing } \\
\text { and/or painting media causes artwork to have different appearances }\end{array}$ \\
\hline VA.O.3.1.2 & Use drawing and/or painting media to create artwork \\
\hline VA.O.3.2.2 & Describe and create artworks using repetition and/or overlapping lines \\
\hline VA.O.3.2.9 & Create patterns using line, shape, and/or color \\
\hline VA.O.3.4.3 & Explain differences in art from varying cultures \\
\hline VA.O.3.4.4 & Create artwork with subjects that reflect present-day culture \\
\hline
\end{tabular}




\begin{tabular}{|l|l|}
\hline VA.O.3.5.1 & Identify different reasons for creating art, example: spiritual purposes \\
\hline VA.O.3.6.2 & Discuss how the senses can be used with the arts disciplines \\
\hline
\end{tabular}

Key Vocabulary: Contour, Line, Shape, Organic Form, Complementary Colors, Color Mixing, ViewFinder, Mandala, Sketching, Unit, Observation, Abstract Design

\section{Materials:}

- White Sketch Paper, 9 X 12" Drawing

- Pencils

- Toilet Paper Tubes

- Paintbrushes

- Egg Cartons, used as Paint Pallets

- Red, Green, and White Tempera Paint

- Newspaper

- Scissors

- Tag Board, cut into Circle

- Black Sharpies

- Yogurt Cups, to wash off brushes as students work

- Water, for clean-up

\section{Critical Questions}

Do you think that your surrounds are art? Do you think the things outside like the trees, streams, and park are a form of art? Why?

Can you think of any artists/artworks that we have looked at in our class that includes pictures of nature outside? Tell me about what kind of objects were in these paintings.

What do you think the artists are trying to tell us about those images?

Why do you think these artists went outside to work on these painting/drawings/sculptures?

What things did you like to look at when you were outside? What kinds of objects are in the pictures that you drew while you were outside?

Can you think of a time that you traveled or looked in a book and saw different places, like beaches, mountains, or deserts? Do they look the same or different than what you saw on our field trip outside of the classroom? How do they look similar, and how do they look different?

Do you think that other countries or other states might look similar to West Virginia? Do you think some countries/states might look different from here?

Let's look at some artworks that show images of different places, kind of like our sketches outside. (Show students examples of natural landscapes and scenery, including imagery of different places.) 


\section{Procedure:}

Place-based education immerses students in their local environments, and so for this project the art students go outside to make field sketches. Depending on a school and county policy concerning fieldtrips, students can visit a local park or the school's outdoor playground. Students bring 8 X 10" sketch paper, drawing pads, and toilet paper viewfinders. Outside the art educator guides a discussion, referencing the critical questions above. The art instructor discusses and points out natural objects that surround the class, during their fieldwork. Students look through their view-finder tubes and sketch what they see, encourage students to fill the paper space, making imagery big and abstract. Students can make more than one sketch if they complete their work early. This activity should take one 40 minute class period.

1. Students choose one of their favorite sketches from field trip.

2. Teacher presents lesson, introduces abstract design and shows works by Paul Klee for inspiration. (Example: Rose Garden, Head of a Man, and Castle and Sun) Klee's use of colors and shapes creates an abstract design.

3. Students sketch over pencil drawings using black sharpie markers. (Note: These outlines will help provide a guideline for students when they begin painting their sketches.)

4. Use tag board circle templates to draw a circle over their sketches. Place sketches on top of the template, trace around the edges with a pencil.

5. Cut around the pencil lines to create a circle to later paste to the round template, developing a Mandala inspired design.

6. Students then paint using red, green, and white tempera paint. (Note: Paint can be mixed.) I recommend giving students paint in stages to avoid over-mixing colors. Students should paint all of their abstract Mandala designs with paint, leaving no empty spaces. See my example.

7. Students then paint their toilet paper tubes/viewfinders, using the same colors, to repeat and unite the compositions.

8. Allow time for paintings and viewfinders to dry. Use tacky glue to attach toilet paper tubes to painting. Exhibit and display works around the school or if possible in the community. (See picture on page 1 for example of a completed work)

\section{Resources:}

http://wveis.k12.wv.us/Teach21/public/cso/popUp.cfm

http://www.mandalaproject.org/What/Index.html

http://www.wvdnr.gov/Wildlife/Ecolog.shtm

http://www.princetonol.com/groups/iad/Files/kara-man.htm 
View-Finder Mandalas; My Natural Environment is a Sacred Place

Students Name:

\begin{tabular}{|c|c|c|c|c|c|}
\hline Criteria & Distinguished & $\begin{array}{l}\text { Above } \\
\text { Mastery }\end{array}$ & Mastery & $\begin{array}{l}\text { Partial } \\
\text { Mastery }\end{array}$ & Novice \\
\hline $\begin{array}{c}\text { Media, } \\
\text { Technique, } \\
\text { and Process }\end{array}$ & $\begin{array}{l}\text { Applies and } \\
\text { models } \\
\text { innovative } \\
\text { problem-solving } \\
\text { skills when } \\
\text { creating } \\
\text { Mandalas }\end{array}$ & $\begin{array}{l}\text { Independently } \\
\text { applies and } \\
\text { explains } \\
\text { problem- } \\
\text { solving skills } \\
\text { when creating } \\
\text { Mandalas }\end{array}$ & $\begin{array}{l}\text { Independently } \\
\text { applies } \\
\text { problem- } \\
\text { solving skills } \\
\text { when creating } \\
\text { Mandalas }\end{array}$ & $\begin{array}{l}\text { Applies problem- } \\
\text { solving skills } \\
\text { when creating } \\
\text { Mandalas }\end{array}$ & $\begin{array}{l}\text { Identifies } \\
\text { problem-solving } \\
\text { skills with } \\
\text { assistance when } \\
\text { creating } \\
\text { Mandalas }\end{array}$ \\
\hline $\begin{array}{l}\text { Elements } \\
\quad \text { and } \\
\text { Principles } \\
\text { of Design }\end{array}$ & $\begin{array}{l}\text { Identifies and } \\
\text { describes } \\
\text { selected } \\
\text { elements and } \\
\text { principles of } \\
\text { design as they } \\
\text { relate to art in } \\
\text { his/her } \\
\text { environment }\end{array}$ & $\begin{array}{l}\text { Independently } \\
\text { identifies } \\
\text { selected } \\
\text { elements and } \\
\text { principles of } \\
\text { design as they } \\
\text { relate to art in } \\
\text { his/her } \\
\text { environment }\end{array}$ & $\begin{array}{l}\text { Identifies } \\
\text { selected } \\
\text { elements and } \\
\text { principles of } \\
\text { design as they } \\
\text { relate to art in } \\
\text { his/her } \\
\text { environment }\end{array}$ & $\begin{array}{l}\text { Identifies with } \\
\text { assistance } \\
\text { selected elements } \\
\text { and principles of } \\
\text { design as they } \\
\text { relate to art in } \\
\text { his/her } \\
\text { environment }\end{array}$ & $\begin{array}{l}\text { Identifies with } \\
\text { repeated } \\
\text { assistance } \\
\text { selected elements } \\
\text { and principles of } \\
\text { design as they } \\
\text { relate to art in } \\
\text { his/her } \\
\text { environment }\end{array}$ \\
\hline $\begin{array}{c}\text { Art History } \\
\text { and } \\
\text { Diversity }\end{array}$ & $\begin{array}{l}\text { Summarizes and } \\
\text { draws } \\
\text { conclusions } \\
\text { regarding the } \\
\text { diverse } \\
\text { characteristics } \\
\text { of a historical } \\
\text { reference of } \\
\text { artworks }\end{array}$ & $\begin{array}{l}\text { Identifies, } \\
\text { differentiates, } \\
\text { and justifies } \\
\text { characteristics } \\
\text { of a historical } \\
\text { reference of } \\
\text { artworks }\end{array}$ & $\begin{array}{l}\text { Identifies } \\
\text { artworks by } \\
\text { linking art to } \\
\text { a historical } \\
\text { reference }\end{array}$ & $\begin{array}{l}\text { Identifies and } \\
\text { classifies } \\
\text { characteristic of } \\
\text { a historical } \\
\text { reference }\end{array}$ & $\begin{array}{l}\text { Identifies limited } \\
\text { characteristic of } \\
\text { a historical } \\
\text { reference }\end{array}$ \\
\hline $\begin{array}{l}\text { Reflections } \\
\text { and } \\
\text { Analysis }\end{array}$ & $\begin{array}{l}\text { Relates and } \\
\text { compares the } \\
\text { content of } \\
\text { artworks in a } \\
\text { global society }\end{array}$ & $\begin{array}{l}\text { Relates and } \\
\text { compares the } \\
\text { content of } \\
\text { artworks to } \\
\text { his/her state } \\
\text { and country }\end{array}$ & $\begin{array}{l}\text { Relates and } \\
\text { compares the } \\
\text { content of } \\
\text { artworks to } \\
\text { home and } \\
\text { community } \\
\text { experiences }\end{array}$ & $\begin{array}{l}\text { Finds, with } \\
\text { assistance, } \\
\text { similarities } \\
\text { between } \\
\text { artworks and } \\
\text { home/community } \\
\text { experiences }\end{array}$ & $\begin{array}{l}\text { Finds, with } \\
\text { considerable } \\
\text { assistance, } \\
\text { similarities } \\
\text { between } \\
\text { artworks and } \\
\text { home/community } \\
\text { experiences }\end{array}$ \\
\hline $\begin{array}{c}\text { Multi- } \\
\text { disciplinary } \\
\text { Connections }\end{array}$ & $\begin{array}{l}\text { Designs and } \\
\text { presents an } \\
\text { original artwork } \\
\text { incorporating } \\
\text { other disciplines }\end{array}$ & $\begin{array}{l}\text { Creating an } \\
\text { original } \\
\text { artwork using } \\
\text { another } \\
\text { discipline }\end{array}$ & $\begin{array}{l}\text { Identifies and } \\
\text { explores } \\
\text { characteristic } \\
\text { of multi- } \\
\text { disciplines } \\
\text { within an } \\
\text { artwork }\end{array}$ & $\begin{array}{l}\text { Recalls } \\
\text { connections } \\
\text { between art and } \\
\text { other disciplines } \\
\text { with assistance }\end{array}$ & $\begin{array}{l}\text { Recognizes } \\
\text { connections } \\
\text { between art and } \\
\text { other disciplines } \\
\text { with } \\
\text { considerable } \\
\text { assistance }\end{array}$ \\
\hline
\end{tabular}




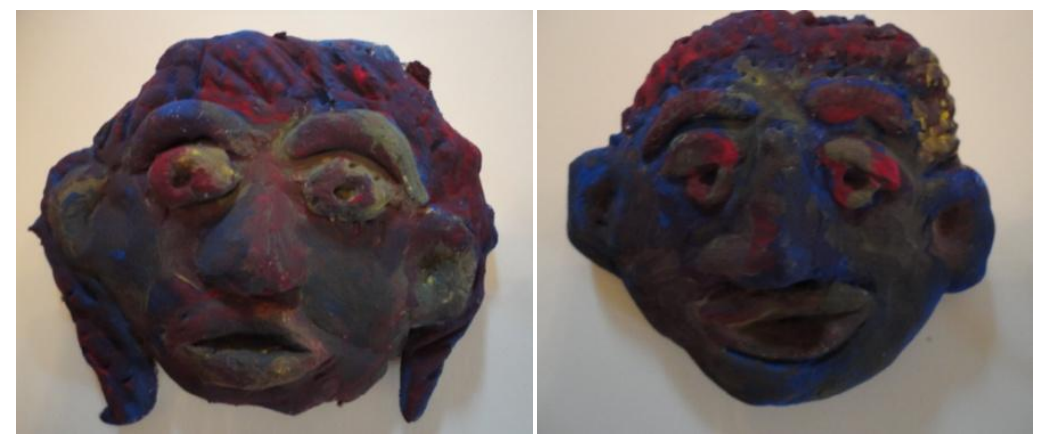

Face jug designs were originally thought to: "Keep the evil spirits out"

\section{Title: Clay Face Mugs Inspired by Ceramic Face Jugs}

Teacher: Marie Drexler

Grade Level: $7^{\text {rd }}$ Grade

\section{Instructional Objectives: West Virginia CSO's}

\section{Students will:}

- Understand processes and techniques in creating art;

- Apply elements and principles of design as they relate to problem-solving skills in the creation of art;

- Identify symbols and ideas to communicate meaning in art;

- Identify how the arts have a history and specific relationship to culture;

- Identify multiple purposes for creating art.

\begin{tabular}{|l|l|}
\hline VA.O.7.1.2 & $\begin{array}{l}\text { Experiment and refine use of selected media, techniques, } \\
\text { technologies, and processes in communication of a personal } \\
\text { experience or an idea. }\end{array}$ \\
\hline VA.O.7.2.7 & Create artwork using actual or simulated texture. \\
\hline VA.O.7.2.9 & $\begin{array}{l}\text { Create three-dimensional forms using symmetrical or } \\
\text { asymmetrical balance. }\end{array}$ \\
\hline VA.O.7.2.13 & $\begin{array}{l}\text { Create three-dimensional human figure using standard } \\
\text { proportions. }\end{array}$ \\
\hline VA.O.7.3.1 & $\begin{array}{l}\text { Integrate symbols and ideas to evoke a specific feeling in an } \\
\text { artwork. }\end{array}$ \\
\hline VA.O.7.4.4 & $\begin{array}{l}\text { Create three-dimensional art based on a specific historical } \\
\text { period. }\end{array}$ \\
\hline VA.O.7.5.1 & Justify reasons for creating works of art and cite examples. \\
\hline
\end{tabular}


Key Vocabulary: Arts and Crafts, Appalachian Culture, Ceramics, Score and Slip, Texture, Proportions, Symbols, Function, Form, Balance, Pinch, Hand building Bisque, Firing, Glaze, Coil, Slab Building

\section{Materials:}

- Pencils

- Clay, Red earthenware clay

- Newspapers

- Rolling pin

- Yogurt cups, for slip dishes

- Water, for slip

- Clay tools

- Plastic knives

- Texture gadgets

- Paper towels

- Plastic bags

- Plastic spray bottles

- Assortment of colored glazes

- Paintbrushes to apply glazes

- Visual examples, internet to view face jug examples

\section{Critical Questions:}

What do you think was the purpose for making face jugs? Why do you think people decorated them with faces? Were these to put on display or to be used?

What do you think folk art means?

Can art also be functional, as well as look aesthetically pleasing?

Can you think of some functional arts that were made by early West Virginians? Quilting is one example; can you think of some others?

Where do you think the clay came from that Appalachian artists used to make these face jugs? Remember this was before we had supply stores like we do today.

Do you think that the people who made these face jugs were artists?

Notice how expressive these faces are, do you think these faces are conveying a message, idea, or a feeling?

\section{Procedure:}

Folk art is art that is associated with a specific culture, usually made by working class people using resources from their home environments. Folk art is primarily functional, which means that it is art which people make to also use. For this lesson we are going to start to think about and discuss folk art, specifically Appalachian face jugs made in West Virginia. Face jugs date back to the early $19^{\text {th }}$ century and are thought to be deeply rooted in the African Slave culture. These vessels are thought to have spiritual meaning, to keep evil spirits out. Face jugs have been found throughout Appalachia, and the tradition of making these continues. For this lesson we are going to make our own folk art inspired face mugs using clay slabs. 
1. Students begin project by sketching out two to three face design ideas and mug shapes. Creativity is encouraged. Talk about emotionalist art, exaggerating expressions to convey an emotion for example The Scream by Edvard Munch. Also, gargoyles are a great inspiration for this lesson; sometimes gargoyles are even sculpted with a combination of both human and animal features, which can also be a great inspiration for student designs. Students must choose one of their face designs and mug shapes before working with the clay. An informal class critique of preliminary sketches could help students determine potential design for their artwork.

2. Art educator does a live demonstration for working with clay, covering hand building techniques including coils, slabs, slipping and scoring. The shape of the mug should have the basic structure of a cylinder, with the height of roughly five to six inches. Students build the basic structure of the mug before working on the facial features and expression. (Note: At the end of each class spray clay vessels with water and cover with plastic bags to keep clay moist.)

3. Following this stage, art educator does a live demonstration on handle making, shaping a mug handle using clay slab and water to smooth out rough areas. Each end of the handle is attached using the slip and score technique. This should take students one full class period; handles should to be propped up using moist towels. (Note: At the end of each class spray clay vessels with water and cover with plastic bags to keep clay moist.)

4. When the base and handle of students' mugs are complete, they can begin to sculpt their face designs by using additive and subtractive technique for sculpting. Texture tools are good for this stage of the mug design.

5. When mug designs are complete, set them to dry and then bisque fired in a kiln.

6. Colored glazes are then painted on bisque fire mugs, and then placed back in the kiln to re-fire for completed artworks.

\section{Resources:}

http://www.youtube.com/watch?v=DSftWvoHF18\&feature=related

http://franksullivanpottery.com/FaceJugHisotry.aspx

http://www.broadstreetantiquemall.com/facejugs/history.html

http://digitalfire.com/4sight/education/pottery_crash_course_for_beginners_8.html

http://www.princetonol.com/groups/iad/lessons/middle/robin-face.htm 


\title{
Clay Face Sculptures Inspired by Ceramic Face Jugs
}

\author{
Students Name:
}

\begin{tabular}{|c|c|c|c|c|c|}
\hline Criteria & $\begin{array}{l}\text { Distinguished } \\
\text { (10 Points) }\end{array}$ & $\begin{array}{c}\text { Above } \\
\text { Mastery } \\
\text { (8 Points) }\end{array}$ & $\begin{array}{l}\text { Mastery } \\
\text { (6 Points) }\end{array}$ & $\begin{array}{c}\text { Partial } \\
\text { Mastery } \\
\text { (4 Points) }\end{array}$ & $\begin{array}{c}\text { Novice } \\
\text { (2 Points) }\end{array}$ \\
\hline $\begin{array}{c}\text { Form/ } \\
\text { Function }\end{array}$ & $\begin{array}{l}\text { Design } \\
\text { considerations } \\
\text { were made, mug } \\
\text { is functional, } \\
\text { handle is } \\
\text { complimentary } \\
\text { and secure }\end{array}$ & $\begin{array}{l}\text { Design was } \\
\text { taken into } \\
\text { account, mug is } \\
\text { functional, } \\
\text { handle is } \\
\text { functional and } \\
\text { secure }\end{array}$ & $\begin{array}{l}\text { Design } \\
\text { executed to } \\
\text { some extent, } \\
\text { mug is useable, } \\
\text { handle size and } \\
\text { connection } \\
\text { needs } \\
\text { improvements }\end{array}$ & $\begin{array}{l}\text { Design needs } \\
\text { considerable } \\
\text { improvements, } \\
\text { not a functional } \\
\text { vessel, handle } \\
\text { needs } \\
\text { substantial } \\
\text { improvements }\end{array}$ & $\begin{array}{l}\text { Design } \\
\text { consideration } \\
\text { not executed, } \\
\text { handle is } \\
\text { missing }\end{array}$ \\
\hline $\begin{array}{c}\text { Glaze and } \\
\text { Color }\end{array}$ & $\begin{array}{l}2 \text { or more colors } \\
\text { were chosen } \\
\text { carefully and } \\
\text { evenly applied }\end{array}$ & $\begin{array}{l}2 \text { or more } \\
\text { colors were } \\
\text { applied, minor } \\
\text { glaze touch-ups } \\
\text { needed }\end{array}$ & $\begin{array}{l}1 \text { or } 2 \text { glazes } \\
\text { were applied, } \\
\text { minor touch-up } \\
\text { needed, some } \\
\text { dripping } \\
\text { present }\end{array}$ & $\begin{array}{l}1 \text { or } 2 \text { colors } \\
\text { chosen } \\
\text { randomly and } \\
\text { applied, major } \\
\text { spots and drips } \\
\text { present }\end{array}$ & $\begin{array}{l}1 \text { color chosen } \\
\text { and hastily } \\
\text { applied, spots } \\
\text { and drips } \\
\text { appear sloppy }\end{array}$ \\
\hline $\begin{array}{c}\text { Surface } \\
\text { Design and } \\
\text { Texture }\end{array}$ & $\begin{array}{l}\text { Mug walls are } \\
\text { considerable } \\
\text { thickness and } \\
\text { smooth surface }\end{array}$ & $\begin{array}{l}\text { Smooth walls } \\
\text { with minor } \\
\text { rough } \\
\text { areas/edges }\end{array}$ & $\begin{array}{l}\text { Smoothing } \\
\text { needs } \\
\text { improvement, } \\
\text { some rough } \\
\text { areas present }\end{array}$ & $\begin{array}{l}\text { Mug surface } \\
\text { not } \\
\text { considerably } \\
\text { smoothed out, } \\
\text { rough areas and } \\
\text { uneven } \\
\text { segments }\end{array}$ & $\begin{array}{l}\text { Substantial } \\
\text { amount of } \\
\text { rough areas and } \\
\text { major uneven } \\
\text { segments }\end{array}$ \\
\hline $\begin{array}{c}\text { Concept/ } \\
\text { Face Design }\end{array}$ & $\begin{array}{l}\text { Unique and } \\
\text { exciting idea, } \\
\text { innovative } \\
\text { creative } \\
\text { problem-solving } \\
\text { skills used }\end{array}$ & $\begin{array}{l}\text { Attractive } \\
\text { design and } \\
\text { interesting } \\
\text { idea, } \\
\text { exceptional use } \\
\text { of creative } \\
\text { problem- } \\
\text { solving skills }\end{array}$ & $\begin{array}{l}\text { High quality } \\
\text { design, } \\
\text { excellent use of } \\
\text { elements and } \\
\text { principles of } \\
\text { deign, creative } \\
\text { problem- } \\
\text { solving skills } \\
\text { used }\end{array}$ & $\begin{array}{l}\text { Pre-planned } \\
\text { design, good } \\
\text { concept, } \\
\text { problem- } \\
\text { solving skills } \\
\text { used }\end{array}$ & $\begin{array}{l}\text { Design idea } \\
\text { and } \\
\text { development } \\
\text { needs } \\
\text { improvements, } \\
\text { basic idea, } \\
\text { problem- } \\
\text { solving skills } \\
\text { used }\end{array}$ \\
\hline $\begin{array}{c}\text { Process: } \\
\text { Completed } \\
\text { Thumbnail } \\
\text { Sketch, and } \\
\text { Mug }\end{array}$ & $\begin{array}{l}\text { Follows } \\
\text { directions, } \\
\text { completes } \\
\text { requirements, } \\
\text { good } \\
\text { craftsmanship }\end{array}$ & $\begin{array}{l}\text { Complete } \\
\text { understanding } \\
\text { of directions } \\
\text { and } \\
\text { requirements, } \\
\text { exceptional } \\
\text { skill with } \\
\text { media }\end{array}$ & $\begin{array}{l}\text { High quality } \\
\text { idea, completes } \\
\text { requirements, } \\
\text { above average } \\
\text { art skills }\end{array}$ & $\begin{array}{l}\text { Meets most } \\
\text { requirements, } \\
\text { average grasp } \\
\text { of directions, } \\
\text { shows some } \\
\text { skill }\end{array}$ & $\begin{array}{l}\text { Meets some } \\
\text { requirements, } \\
\text { skills and effort } \\
\text { below } \\
\text { expectations }\end{array}$ \\
\hline
\end{tabular}

\section{Additional Comments:}




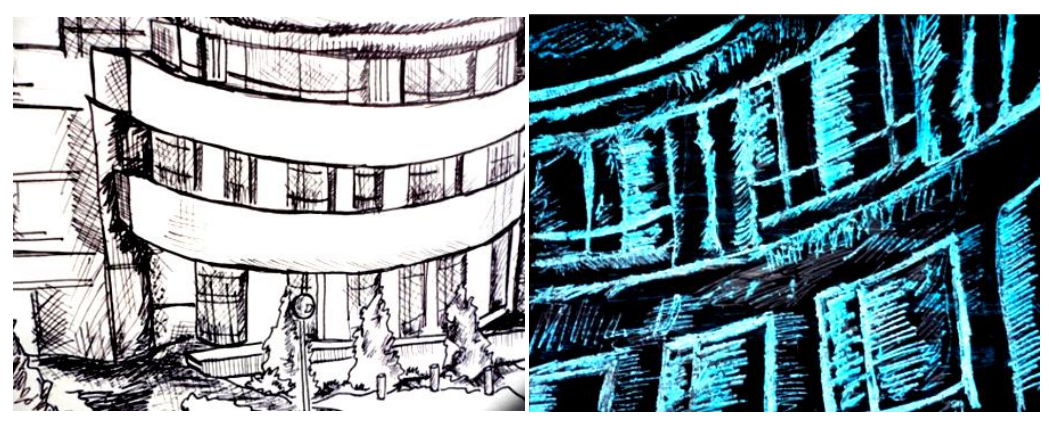

Diptych Art: Value and Shading

Title: West Virginia Black and White Architecture Rendering

Teacher: Marie Drexler

Grade Level: Art II

\section{Instructional Objectives: West Virginia CSO's}

\section{Students will:}

- Understand the processes and techniques in creating art

- Indentify selected elements and principles of design as they relate to art and the environment

- Apply problem-solving skills when creating art relative to subject matter, symbols, and ideas

- Analyze works of art that reflect different styles and time periods

- Identify multiple purposes for creating art

\begin{tabular}{|l|l|}
\hline VA.S. VAII.1.2 & $\begin{array}{l}\text { Create a variety of two-dimensional artworks to communicate } \\
\text { ideas and explore expressive qualities. }\end{array}$ \\
\hline VA.S. VAII.2.3 & $\begin{array}{l}\text { Students will construct and design two-dimensional artworks } \\
\text { that use principles of design to solve specific art problems. }\end{array}$ \\
\hline VA.S. VAII.3.1 & $\begin{array}{l}\text { Students will reflect, through discussion and in sketch books, } \\
\text { how architectural structures differ visually, spatially, } \\
\text { intellectually, and functionally, and describe how these } \\
\text { differences are results of historical and cultural context as } \\
\text { related to Morgantown, WV history. }\end{array}$ \\
\hline VA.S. VAII.4.3 & $\begin{array}{l}\text { Students will demonstrate in their own artwork a relationship } \\
\text { to history, aesthetics, and culture of Morgantown, WV. }\end{array}$ \\
\hline VA.S. VAII.6.2 & $\begin{array}{l}\text { Students will apply creative problem-solving techniques to } \\
\text { produce a multi-disciplinary artwork. }\end{array}$ \\
\hline
\end{tabular}


Key Vocabulary: Perspective, Value, Shadow, Cross-Hatch, Stippling, Hatching, Architecture Renderings, Unity, Balance, Diptych, Positive and Negative Space, Depth, Dimension,

\section{Materials:}

- Pencil

- Rulers

- Sketchbooks/scrap paper

- Transfer paper

- Digital camera

- Computer with printer

- Black ink pens

- Black fine-point sharpies

- Black scratchboard sheets (Alternative: Crayons, Black tempera paint, and Liquid dish soap)

- White 80lb drawing paper

- Rubber Erasers

- Scratchboard tools (or nails)

\section{Critical Questions:}

Do you think architecture design is an art form?

What do you think are the steps in the (architecture) design process?

What do you think are the priorities of an architect, and what things effect design decisions?

Do the building designs in our local community work collectively? Do they have a cohesive style?

Did any buildings seem out of place, why? Explain.

What elements of design were seen in the architecture on our fieldtrip to the local downtown? (Reminder: How did the architect use line, shape, texture, color, space?)

What principles of design were seen in the architecture on our fieldtrip to the local downtown? (Reminder: How did the architect create balance, unity, emphasis, repetition, pattern, contract, proportion, and scale?)

How does the look of a place change and/ or evolve with time?

\section{Procedure:}

Students take a fieldtrip through the downtown that features local architecture sites and community landmarks. All students participate in a walking tour of the downtown. During this tour students develop sketches and take photographs of local architecture and community 
landmarks for documentation and later use. Students research historical information about the architecture site or landmark they will use to create the two-dimensional diptych rendering. After returning to the classroom and discussing the critical questions listed above, introduce onepoint-perspective. The teacher introduces one-point perspective drawing, in which parallel lines all meet at a single vanishing point. Art Educators also demonstrates how to create a strong composition focusing on the principles of design including balance and proportion.

For two-dimensional pen and ink compositions, students learn the process and technique for creating value/ shading using cross-hatching, hatching, and stippling.

1. Students draw, their architecture site or community landmark, starting with a horizon line and vanishing point, with pencil.

2. Students use rulers to draw building lines and to help lead parallel lines to the imaginary vanishing point.

3. When preliminary pencil drawings are complete, students use fine point ink pens to create value and shading, using techniques mentioned above.

4. After letting the ink dry for a day, students can erase pencil lines using a kneaded eraser.

Art Educator demonstrates how to create a drawing using black scratchboard. Scratchboard is similar to a photography negative, where the drawings details are white with a black backdrop.

1. Students pick one segment of their architecture/ landscape to enhance and enlarge for their scratchboard drawing. Students develop two or three thumbnail sketches to plan out scratchboard compositions.

2. Students use calligraphy pens, nails, or broken plastic forks spokes to draw an enlarged detail from their previous work.

3. Value and shading techniques are applied to create depth and to create detail.

4. Pen and ink and scratchboard drawings should be matted and hung as a diptych artwork.

\section{Resources:}

http://www.ehow.com/how_12013578_make-own-scratchboard.html

http://www.hsv.k12.al.us/schools/art/dixon/architecture.htm

$\underline{\text { http://www.artyfactory.com/pen_and_ink_drawing/ink_drawing/pen_and_ink_drawing_5.htm }}$

http://www.princetonol.com/groups/iad/lessons/middle/perspective.htm

http://www.explore-drawing-and-painting.com/perspective-drawing.html 


\section{West Virginia Black and White Architecture Rendering}

Students Name:

\begin{tabular}{|c|c|c|c|c|c|}
\hline Criteria & $\begin{array}{c}\text { Distinguished } \\
\text { (10 Points) }\end{array}$ & $\begin{array}{c}\text { Above } \\
\text { Mastery } \\
\text { (8 Points) }\end{array}$ & $\begin{array}{l}\text { Mastery } \\
\text { (6 Points) }\end{array}$ & $\begin{array}{c}\text { Partial } \\
\text { Mastery } \\
\text { (4 Points) }\end{array}$ & $\begin{array}{c}\text { Novice } \\
\text { (2 Points) }\end{array}$ \\
\hline $\begin{array}{c}\text { Process: } \\
\text { Completed } \\
\text { sketch, Ink } \\
\text { Drawing, and } \\
\text { Scratchboard }\end{array}$ & $\begin{array}{l}\text { Follows } \\
\text { directions, } \\
\text { completes } \\
\text { requirements, } \\
\text { good } \\
\text { representations }\end{array}$ & $\begin{array}{l}\text { Complete } \\
\text { understanding } \\
\text { of directions } \\
\text { and } \\
\text { requirements, } \\
\text { exceptional } \\
\text { skill with } \\
\text { media }\end{array}$ & $\begin{array}{l}\text { High quality } \\
\text { idea, } \\
\text { completes } \\
\text { requirements, } \\
\text { above average } \\
\text { art skills }\end{array}$ & $\begin{array}{l}\text { Meets most } \\
\text { requirements, } \\
\text { average grasp } \\
\text { of directions, } \\
\text { shows some } \\
\text { skill }\end{array}$ & $\begin{array}{l}\text { Meets some } \\
\text { requirements, } \\
\text { skills and } \\
\text { effort below } \\
\text { expectations }\end{array}$ \\
\hline $\begin{array}{c}\text { Elements and } \\
\text { Principles of } \\
\text { Design }\end{array}$ & $\begin{array}{l}\text { Confident and } \\
\text { clear use of } \\
\text { design } \\
\text { principles/ } \\
\text { elements }\end{array}$ & $\begin{array}{l}\text { Complete } \\
\text { understanding } \\
\text {, use of } \\
\text { design } \\
\text { principles/ } \\
\text { elements }\end{array}$ & $\begin{array}{l}\text { Organizes } \\
\text { artwork using } \\
\text { design } \\
\text { principles/ } \\
\text { elements }\end{array}$ & $\begin{array}{l}\text { Organizes, } \\
\text { with } \\
\text { assistance, } \\
\text { artwork using } \\
\text { design } \\
\text { principles/ } \\
\text { elements }\end{array}$ & $\begin{array}{l}\text { Organizes, } \\
\text { with } \\
\text { considerable } \\
\text { assistance, } \\
\text { artwork using } \\
\text { design } \\
\text { principles/ } \\
\text { elements }\end{array}$ \\
\hline $\begin{array}{c}\text { Shading and } \\
\text { Value }\end{array}$ & $\begin{array}{l}\text { Exceptional skill } \\
\text { creating textures } \\
\text { and values with } \\
\text { pen and ink }\end{array}$ & $\begin{array}{l}\text { Variety of } \\
\text { textures and } \\
\text { values } \\
\text { created with } \\
\text { pen and ink }\end{array}$ & $\begin{array}{l}\text { Fine skill } \\
\text { shown and use } \\
\text { of textures } \\
\text { and values } \\
\text { created with } \\
\text { pen and ink }\end{array}$ & $\begin{array}{l}\text { Standard use } \\
\text { of texture and } \\
\text { values created } \\
\text { with pen and } \\
\text { ink, }\end{array}$ & $\begin{array}{l}\text { Below average } \\
\text { use of texture } \\
\text { and value, } \\
\text { needs } \\
\text { improvements }\end{array}$ \\
\hline $\begin{array}{c}\text { Overall } \\
\text { Composition }\end{array}$ & $\begin{array}{l}\text { Original and } \\
\text { creative } \\
\text { composition, } \\
\text { visually } \\
\text { interesting }\end{array}$ & $\begin{array}{l}\text { Unique, very } \\
\text { original, and } \\
\text { individually } \\
\text { designed }\end{array}$ & $\begin{array}{l}\text { Generally } \\
\text { original, } \\
\text { expressive } \\
\text { and } \\
\text { interesting } \\
\text { design }\end{array}$ & $\begin{array}{l}\text { Average } \\
\text { originality, } \\
\text { possible } \\
\text { copying, } \\
\text { standard } \\
\text { imagery }\end{array}$ & $\begin{array}{l}\text { Little to no } \\
\text { originality in } \\
\text { design, } \\
\text { common } \\
\text { imagery and } \\
\text { basic } \\
\text { construction }\end{array}$ \\
\hline Craftsmanship & $\begin{array}{l}\text { Neat, clean, and } \\
\text { complete, skillful } \\
\text { use of media, } \\
\text { effective use of } \\
\text { positive and } \\
\text { negative space }\end{array}$ & $\begin{array}{l}\text { Organized } \\
\text { and complete, } \\
\text { skillful use of } \\
\text { media, good } \\
\text { use of } \\
\text { positive and } \\
\text { negative } \\
\text { space }\end{array}$ & $\begin{array}{l}\text { Good lines } \\
\text { and use of } \\
\text { media, } \\
\text { organized } \\
\text { design with } \\
\text { above average } \\
\text { use of positive } \\
\text { and negative } \\
\text { space }\end{array}$ & $\begin{array}{l}\text { Average use of } \\
\text { media and } \\
\text { techniques, } \\
\text { areas need } \\
\text { cleaned up, } \\
\text { standard use of } \\
\text { positive and } \\
\text { negative space }\end{array}$ & $\begin{array}{l}\text { Standard use } \\
\text { of media and } \\
\text { techniques, } \\
\text { overall } \\
\text { craftsmanship } \\
\text { needs major } \\
\text { improvements }\end{array}$ \\
\hline
\end{tabular}

\section{Additional Comments:}

